\title{
A nipple shield delivery system for oral drug delivery to breastfeeding infants : Microbicide delivery to inactivate HIV
}

Article

Accepted Version

Gerrard, S. E., Baniecki, M. L., Sokal, D. C., Morris, M. K., Urdaneta-Hartmann, S., Krebs, F. C., Wigdahl, B., Abrams, B. F., Hanson, C. V., Slater, N. K.H. and Edwards, A. D. (2012) A nipple shield delivery system for oral drug delivery to breastfeeding infants: Microbicide delivery to inactivate HIV. International Journal of Pharmaceutics, 434 (1-2). 224- 234. ISSN 0378-5173 doi:

https://doi.org/10.1016/j.ijpharm.2012.05.035 Available at https://centaur.reading.ac.uk/28406/

It is advisable to refer to the publisher's version if you intend to cite from the work. See Guidance on citing.

Published version at: http://www.sciencedirect.com/science/article/pii/S0378517312005200

To link to this article DOI: http://dx.doi.org/10.1016/j.ijpharm.2012.05.035

Publisher: Elsevier

All outputs in CentAUR are protected by Intellectual Property Rights law, including copyright law. Copyright and IPR is retained by the creators or other copyright holders. Terms and conditions for use of this material are defined in the End User Agreement. 


\section{www.reading.ac.uk/centaur}

\section{CentAUR}

Central Archive at the University of Reading

Reading's research outputs online 


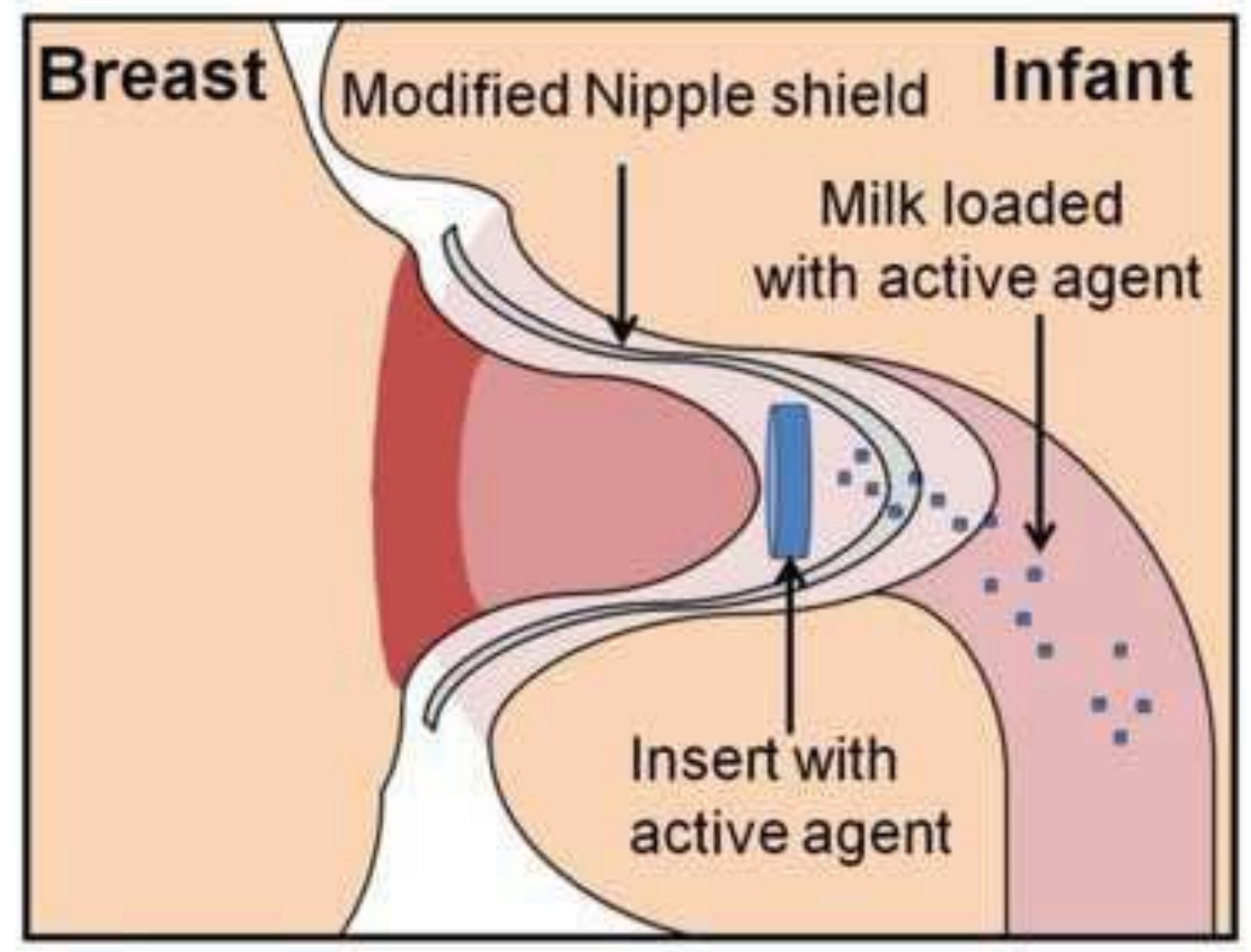




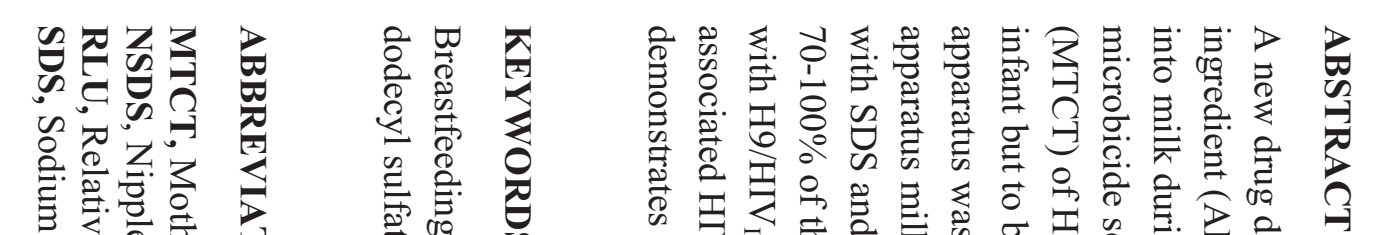

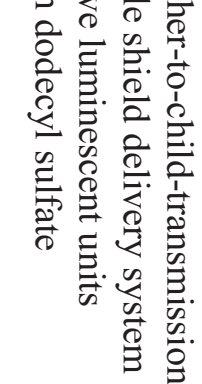

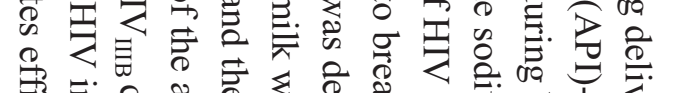

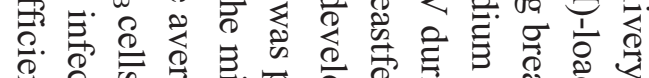

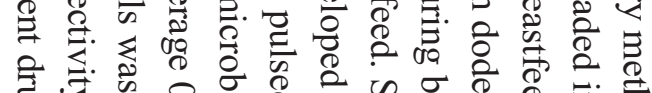

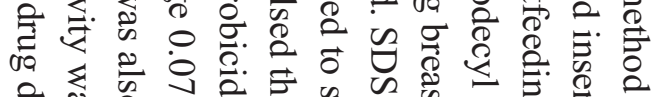

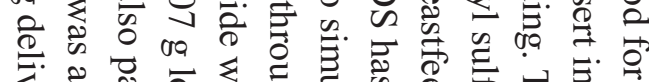

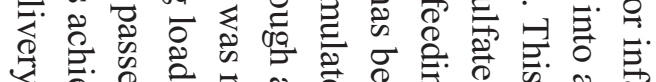

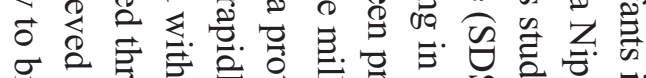

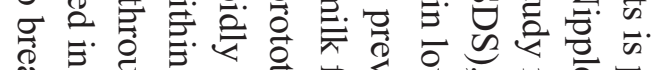

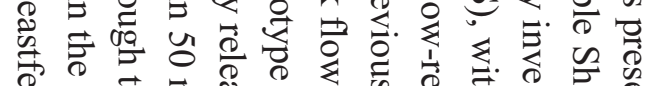

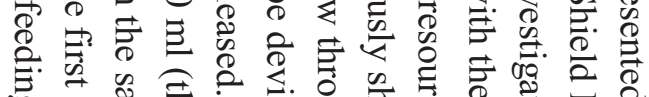

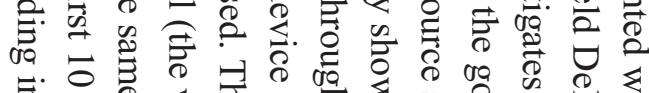

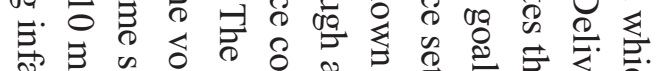

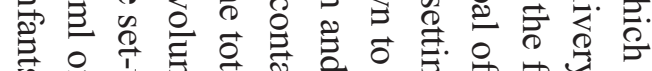

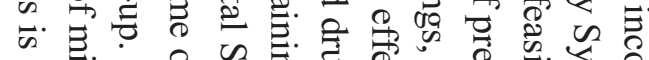
层 Q 궁 政.

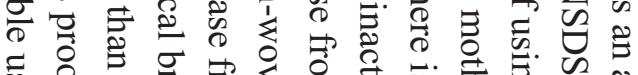

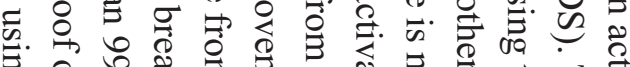
蒋

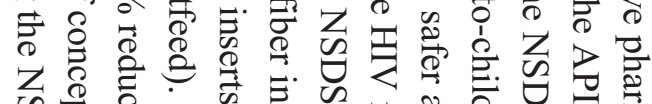

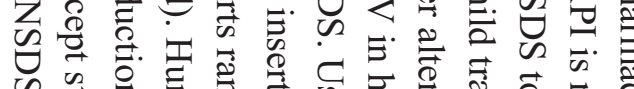

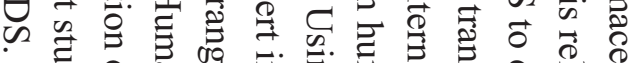

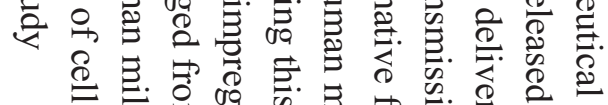

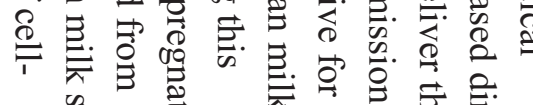

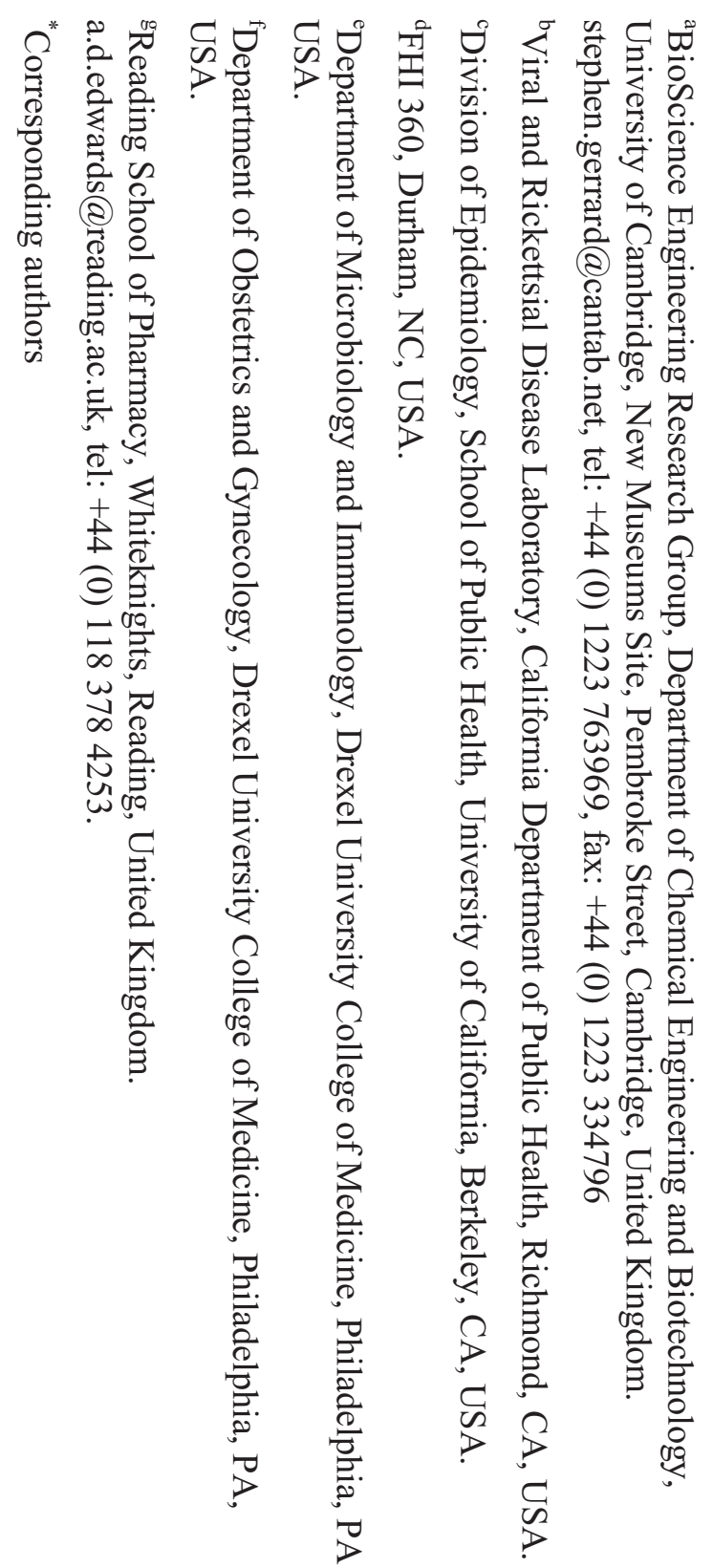

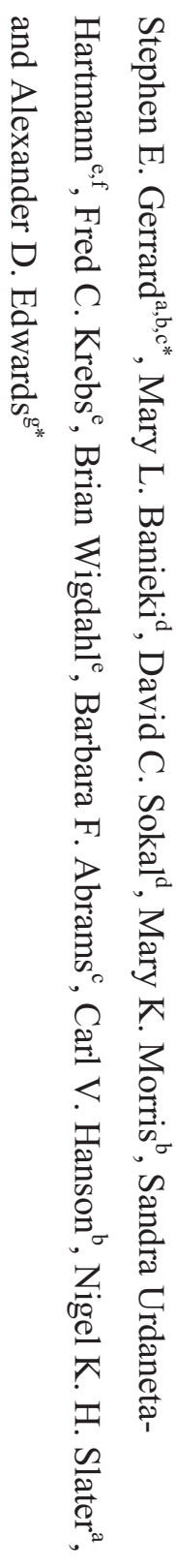

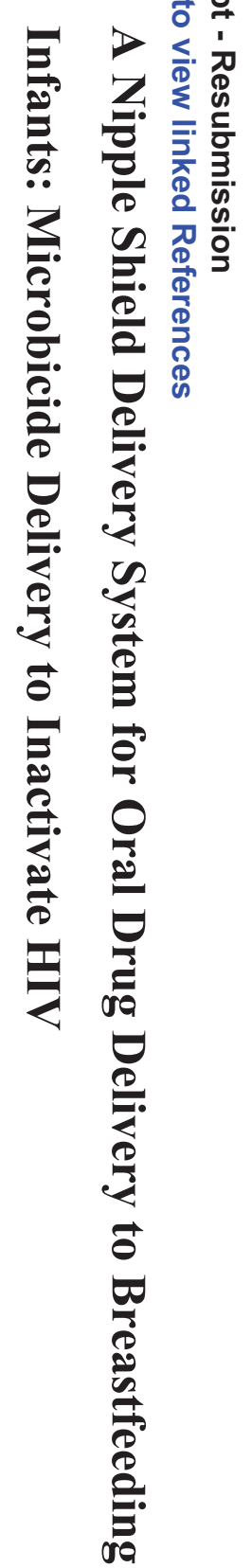




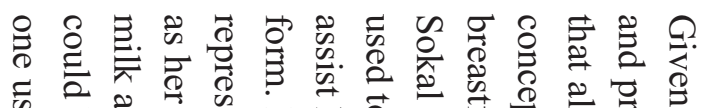
䒴

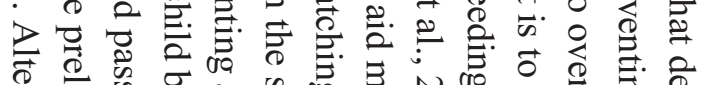

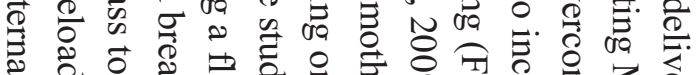

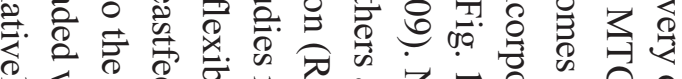

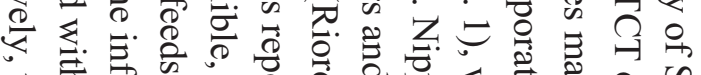

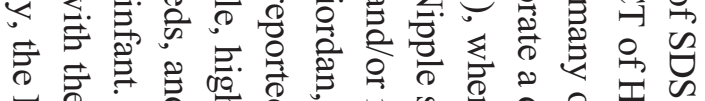

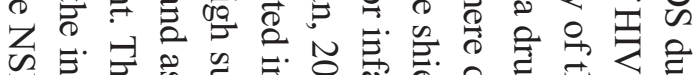

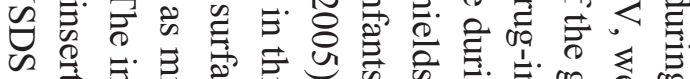

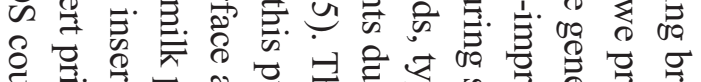

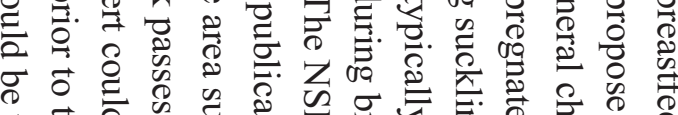

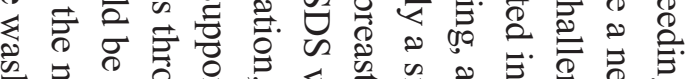

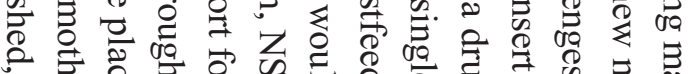

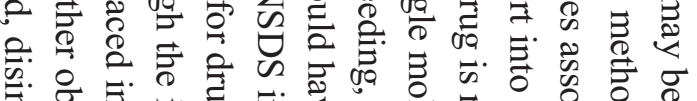

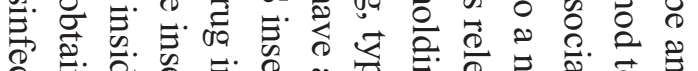

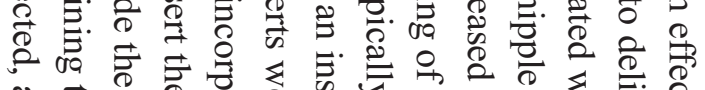

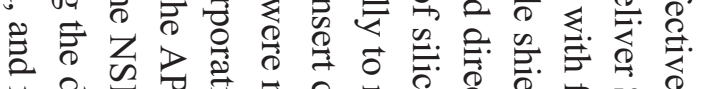

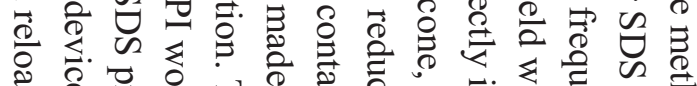

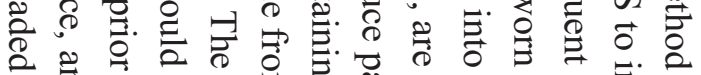
¿

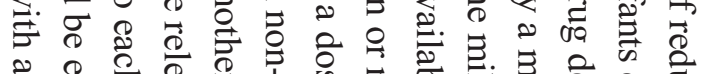

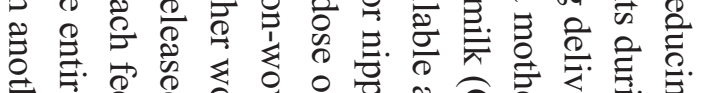

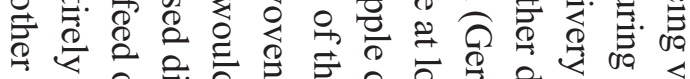
焉.

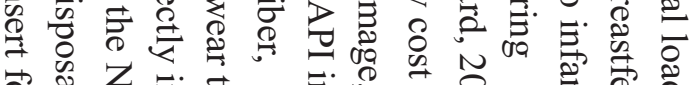

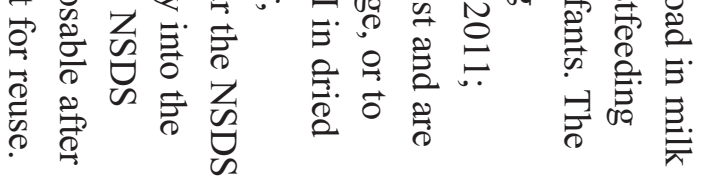

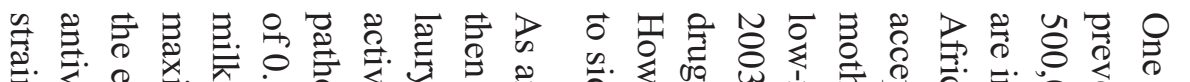

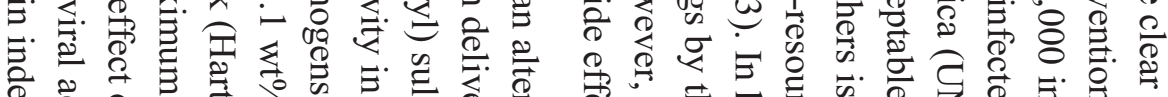
웡

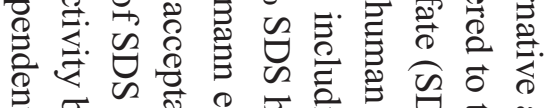

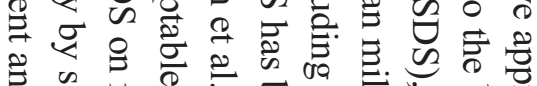

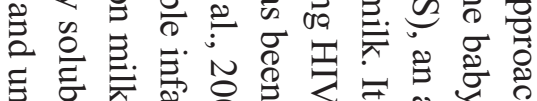

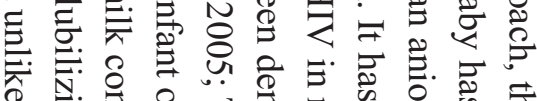

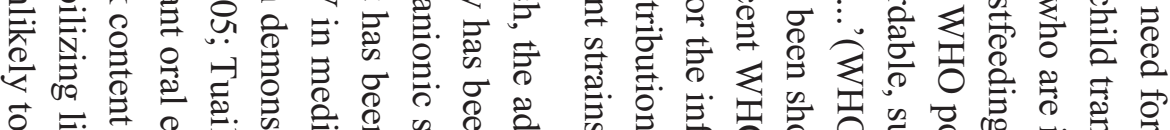

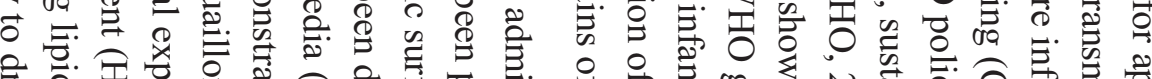
당

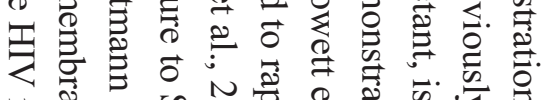

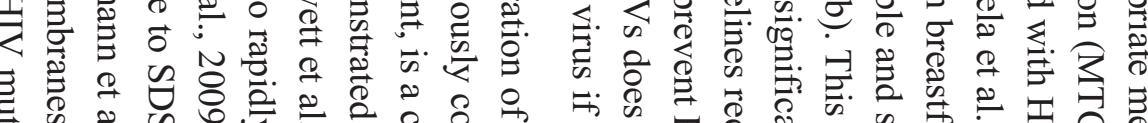

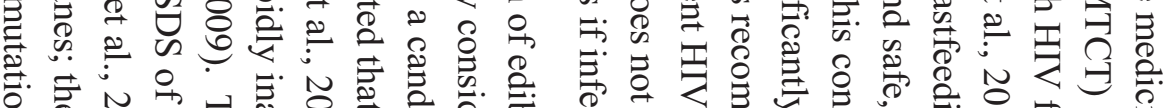

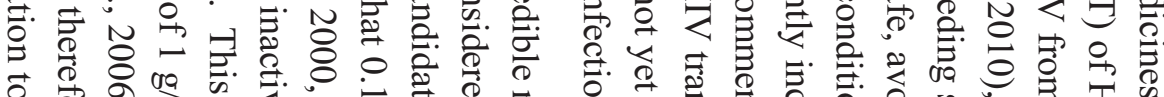
$\overrightarrow{0} 0$

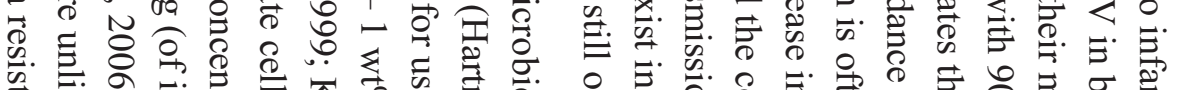

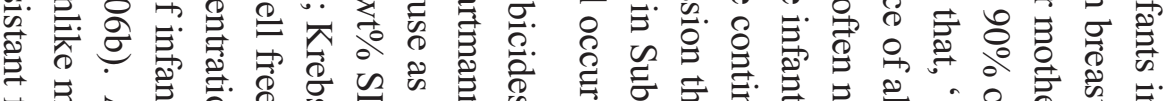

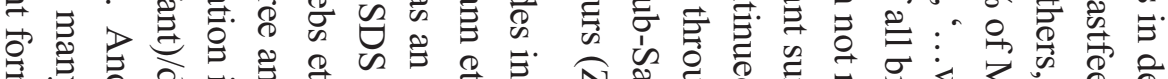

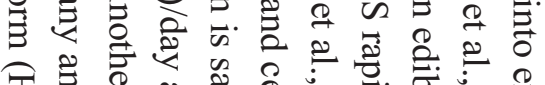

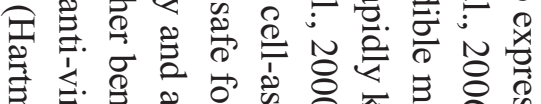

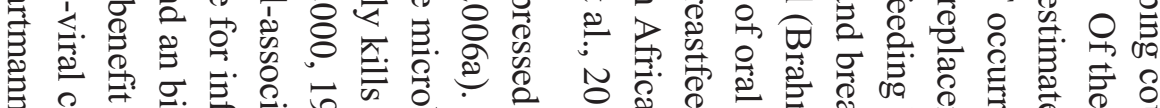

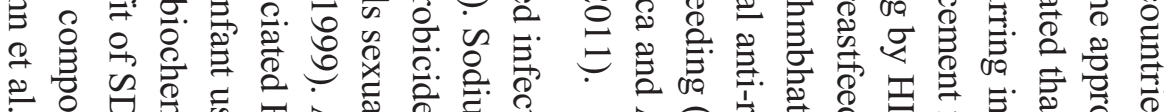

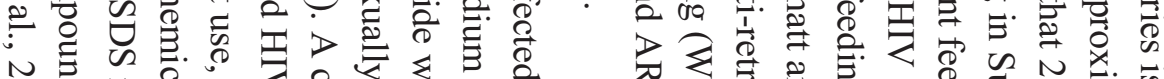

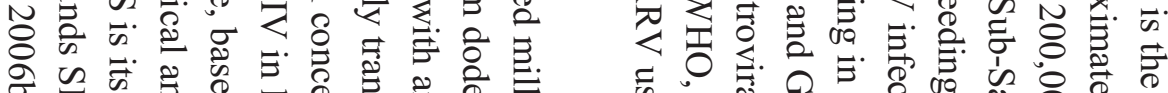

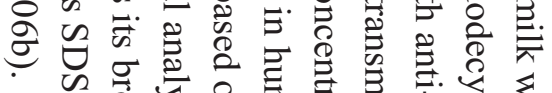

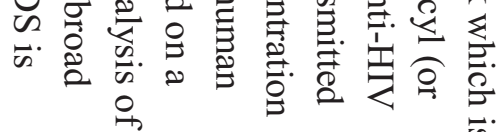

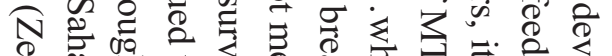

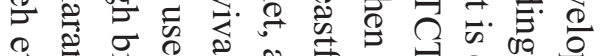

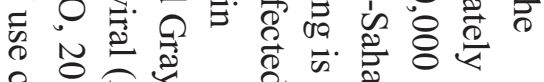

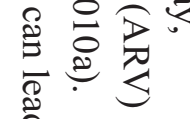

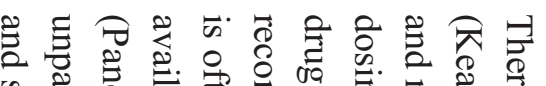

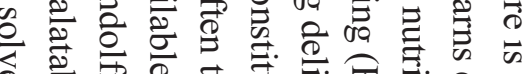

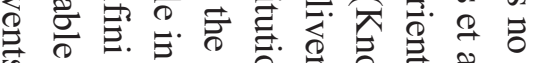

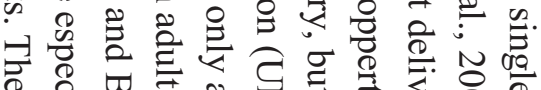
웅.

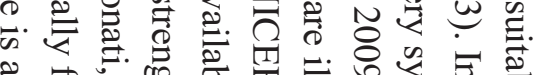

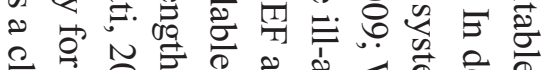

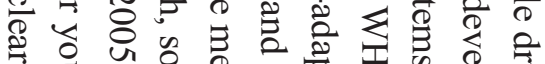

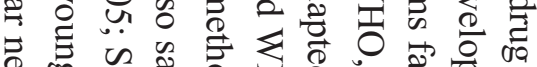

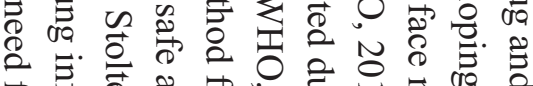

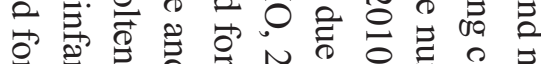
空

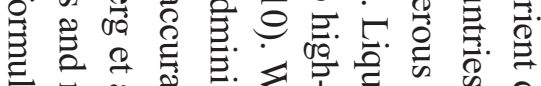

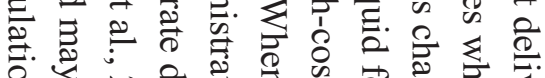

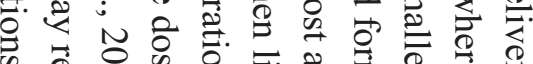
क

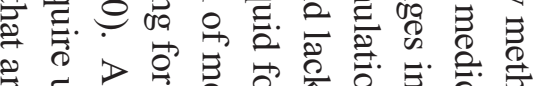

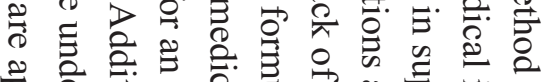

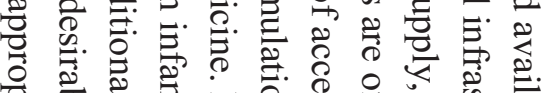

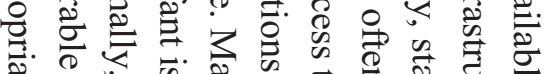
बै $\overrightarrow{0}$ :

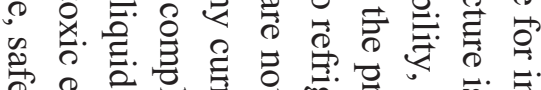
$\overrightarrow{0}$ 웅

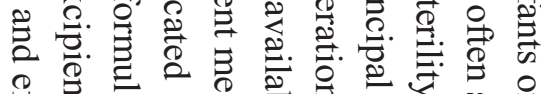

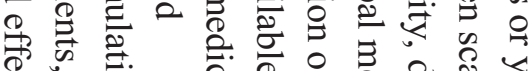

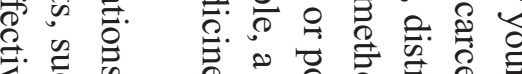
ठ항

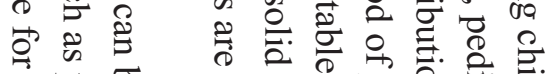

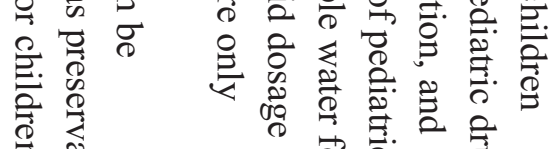
के

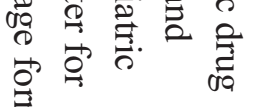




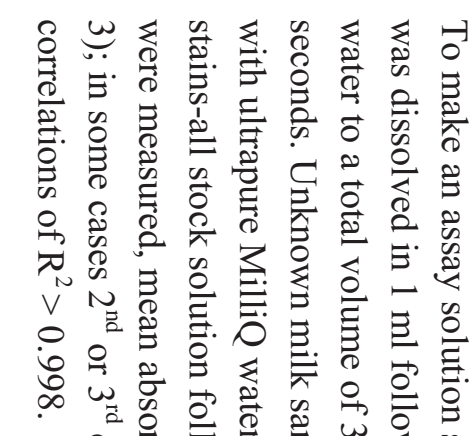

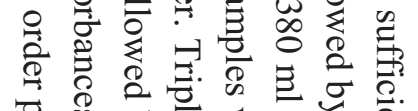

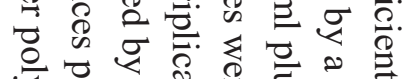

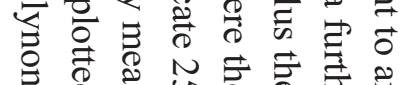

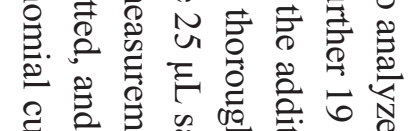

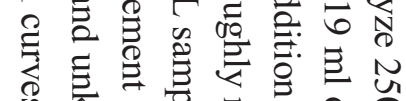

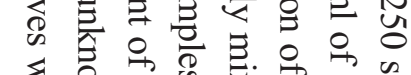

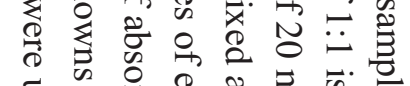

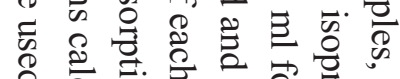
文施

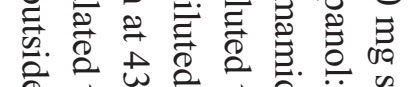

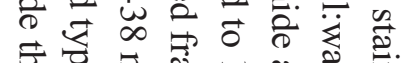

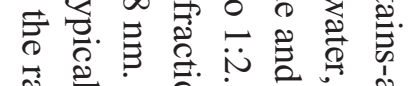

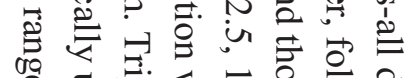

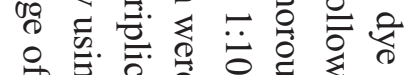

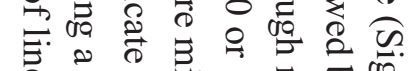

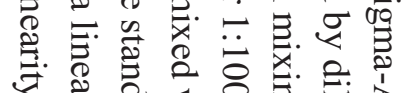

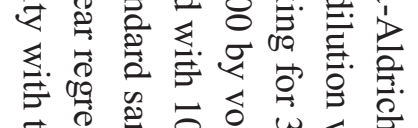

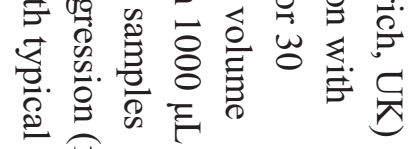

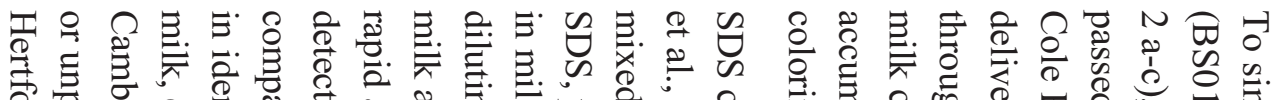

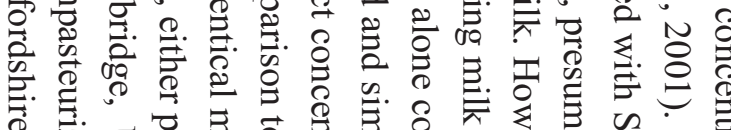

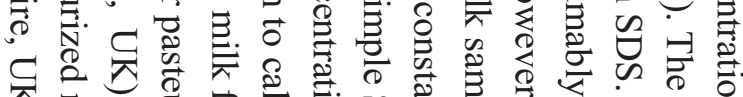

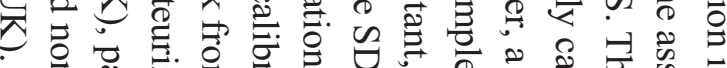

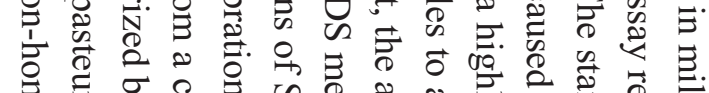

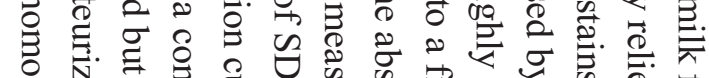

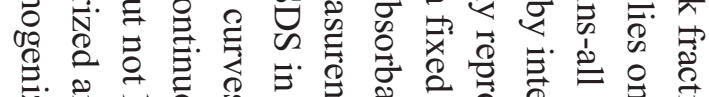

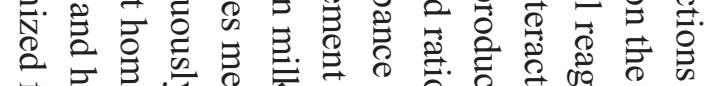

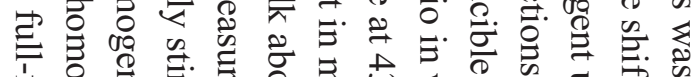

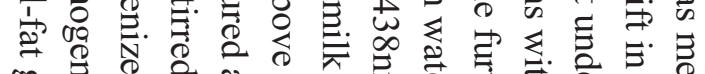

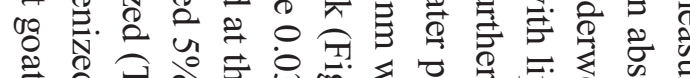

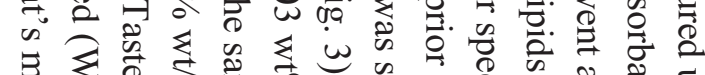

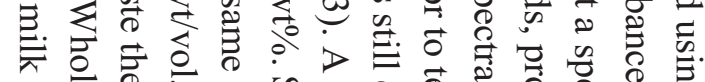

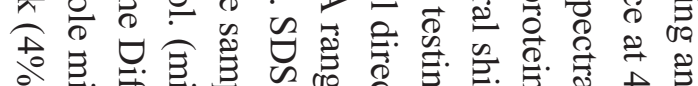

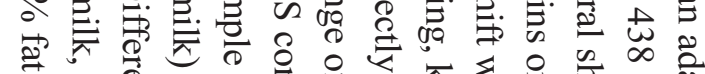
«

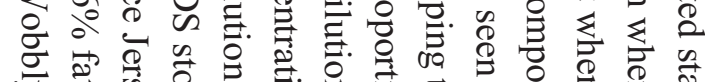

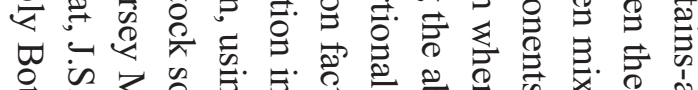

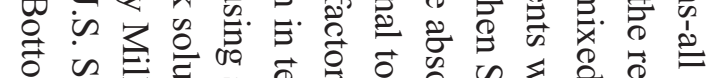

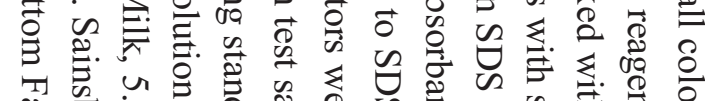

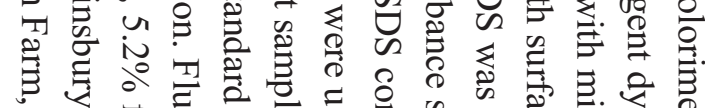

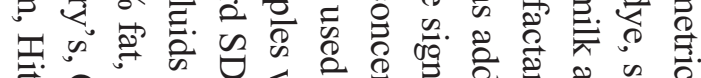

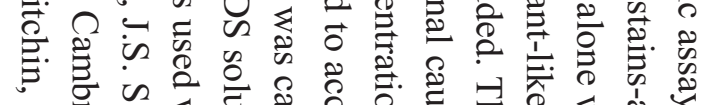

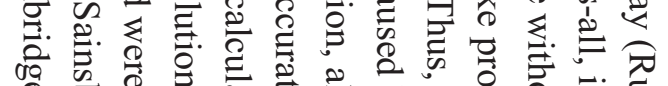

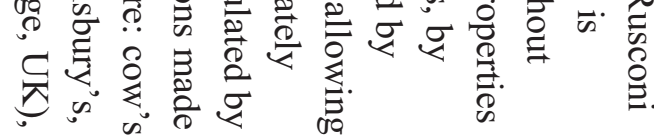

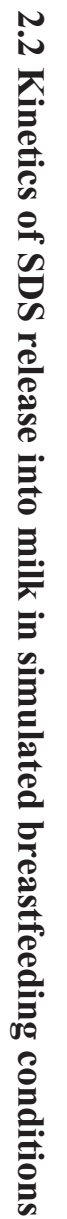

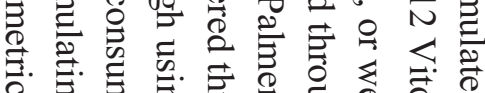
की

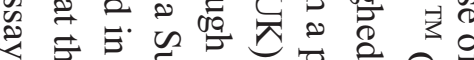
०े के है

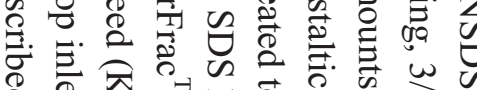

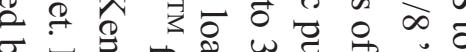

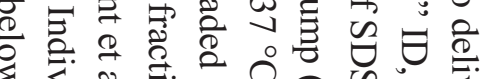

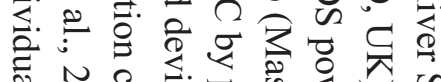
ڤ్రి

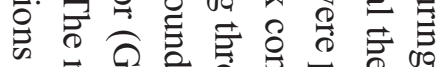

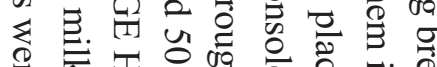

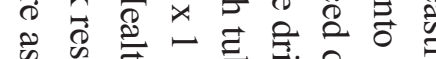

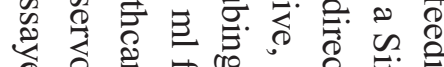

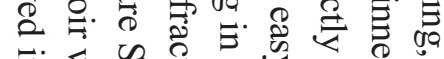

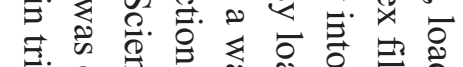
它.

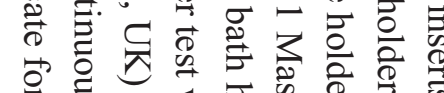

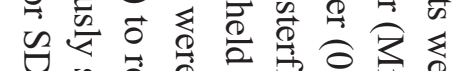

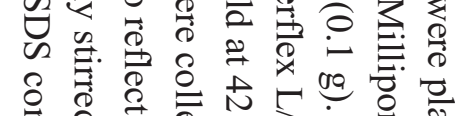

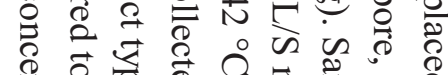

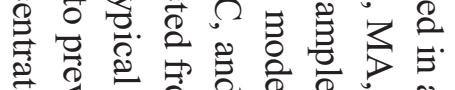

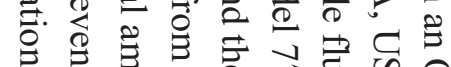

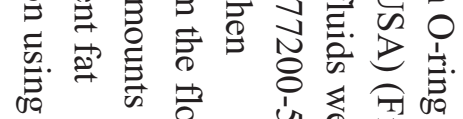

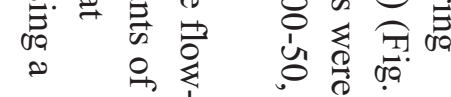

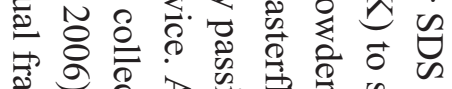

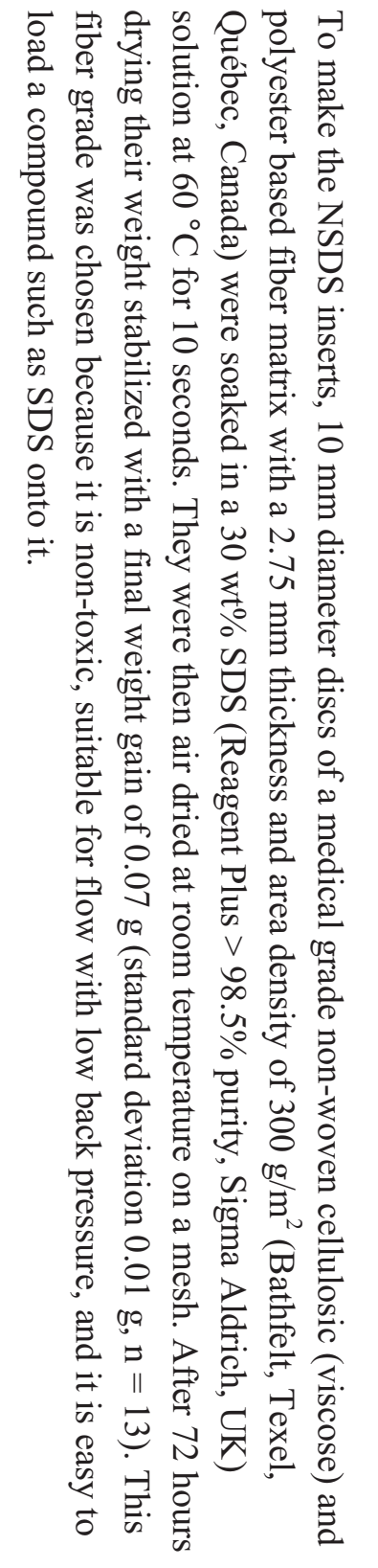

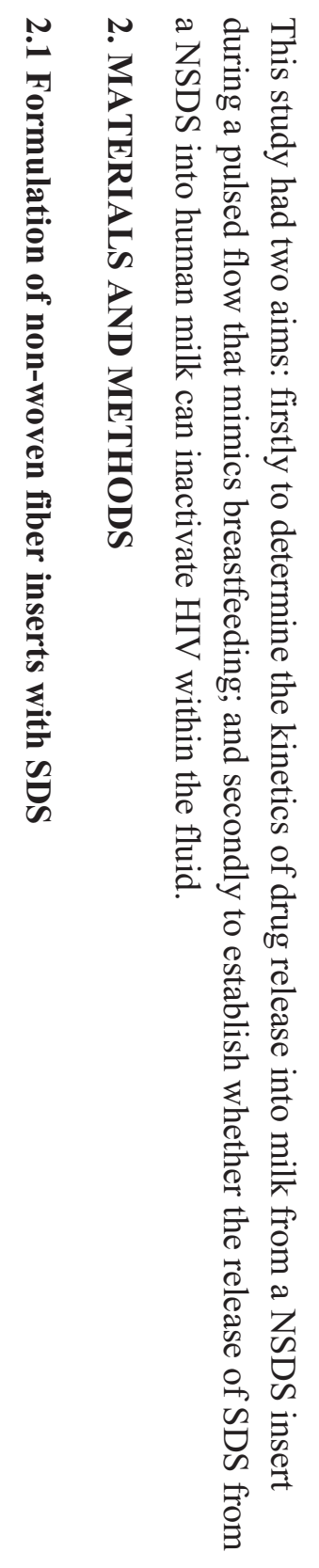




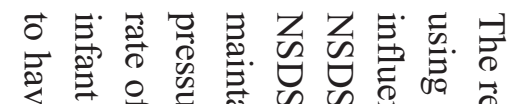

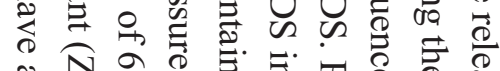
药

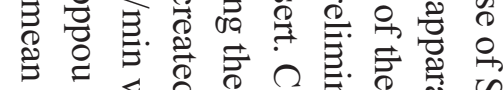

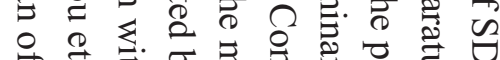
出

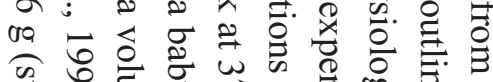

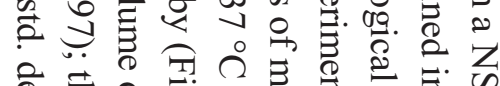
? 要

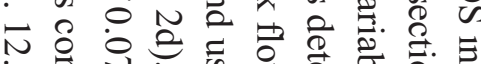

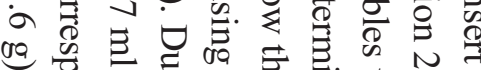

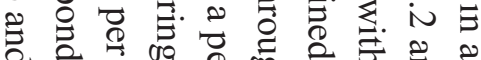

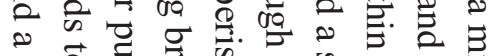

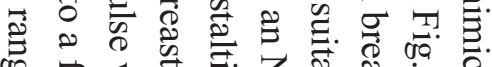

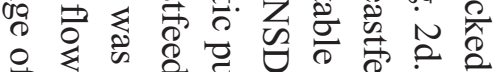
\&

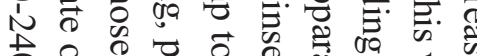

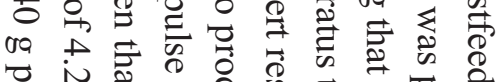
ब \&. ․

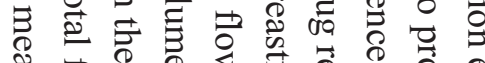

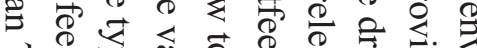
म

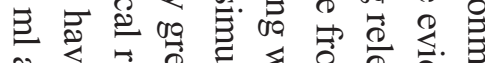

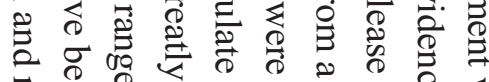

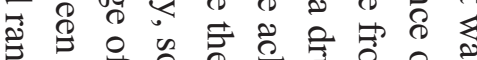
$\rightarrow 0$ क 0 क

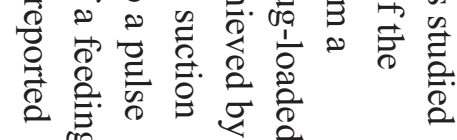

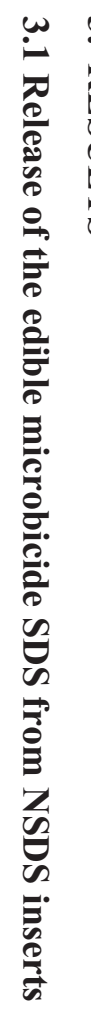

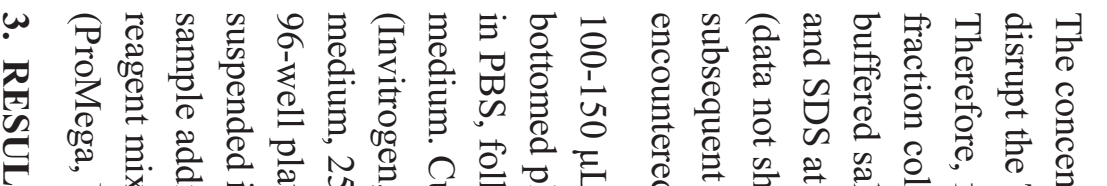

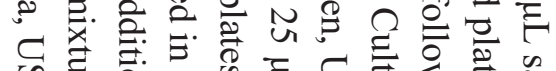

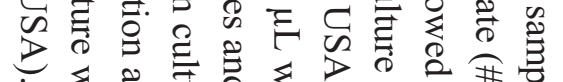

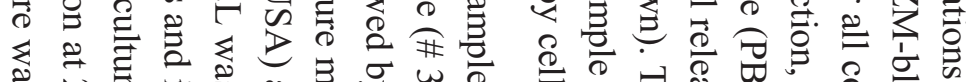

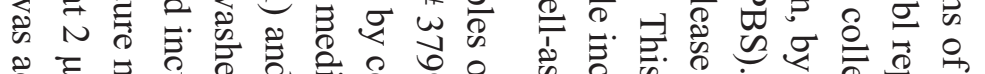

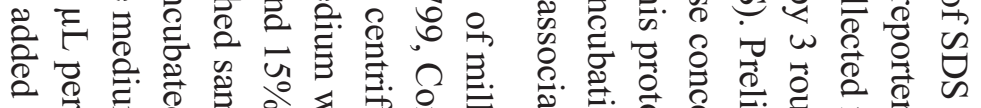

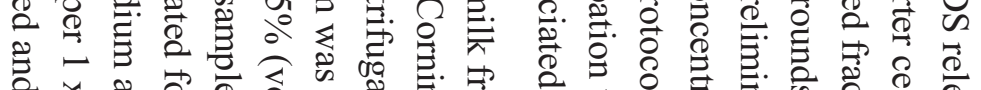

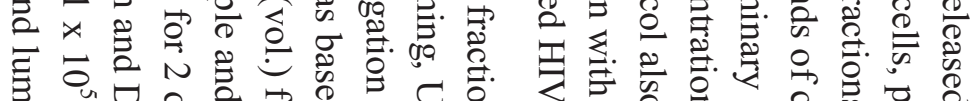

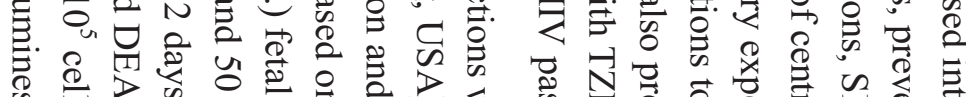

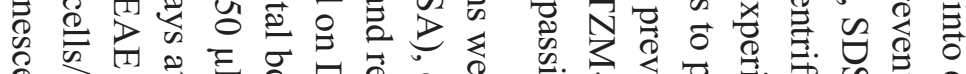

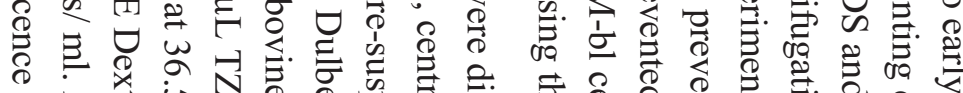

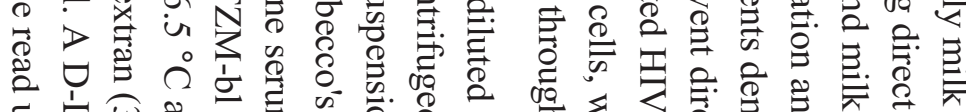
帛.

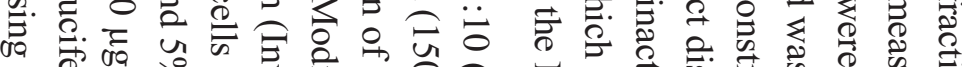

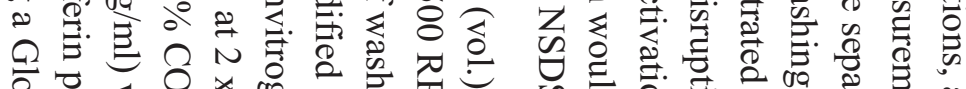

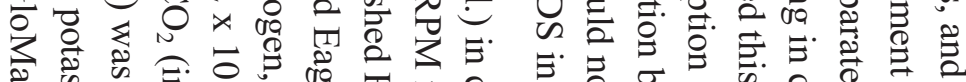

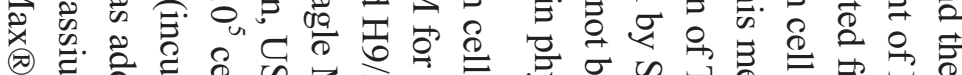

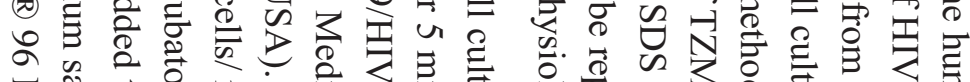

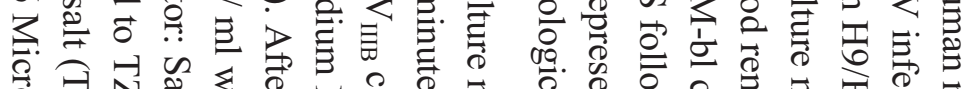

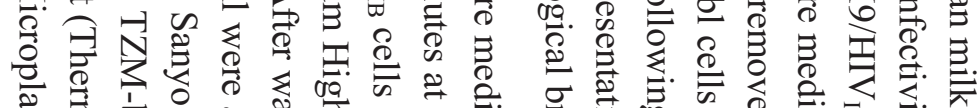

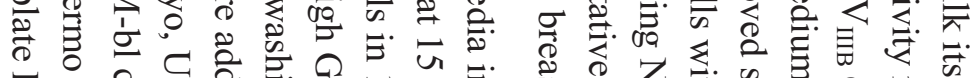

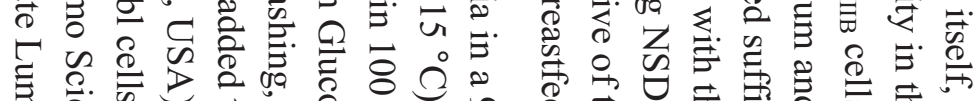

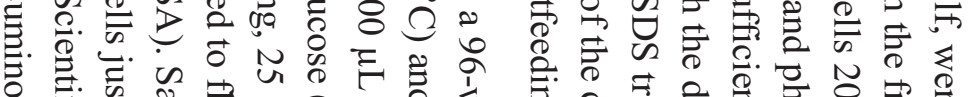

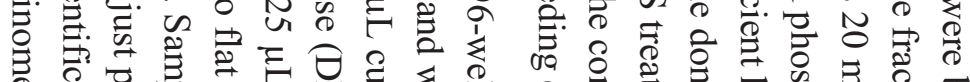

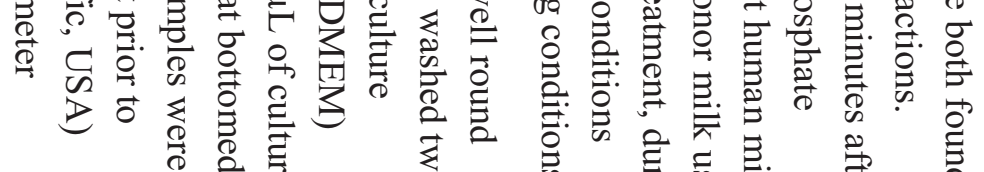

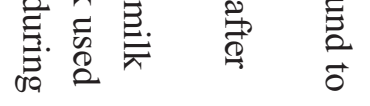

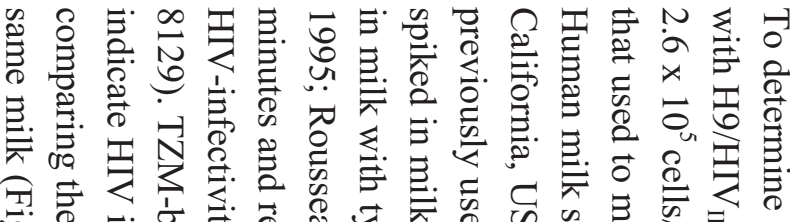

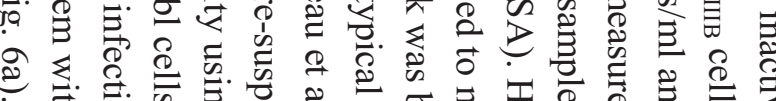
S. 嵌

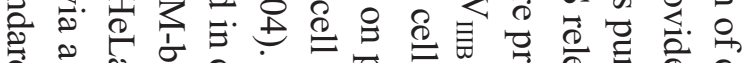

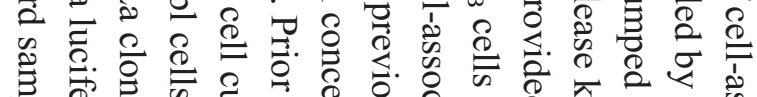

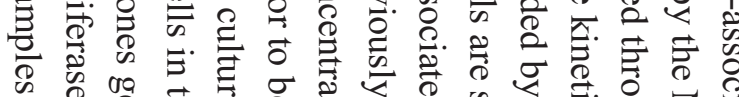

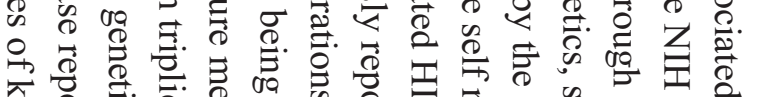

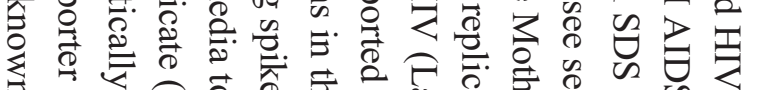

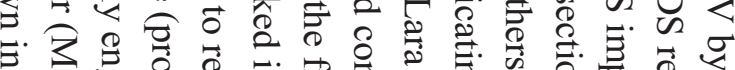

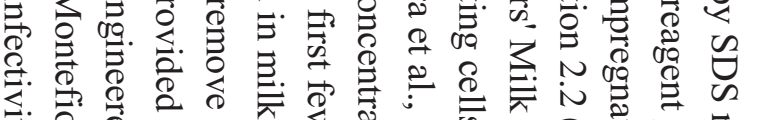

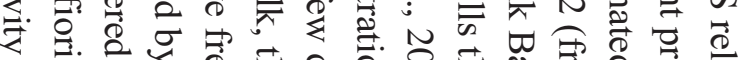

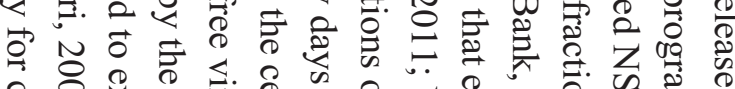

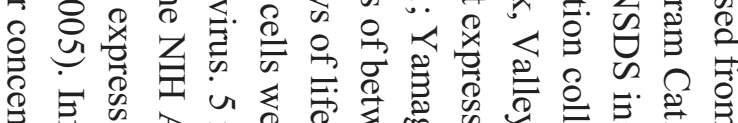

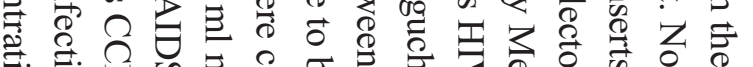

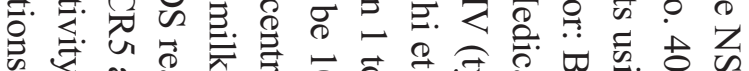

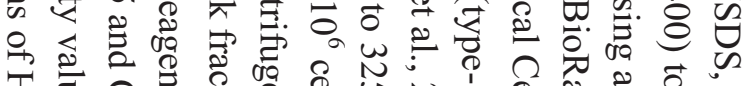

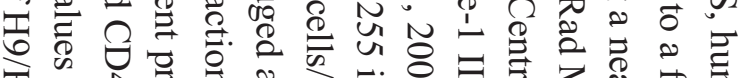

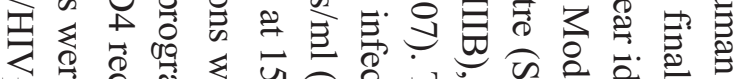

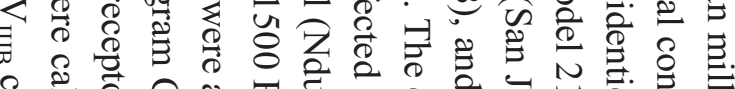

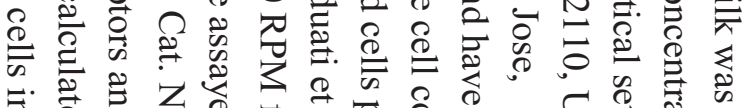

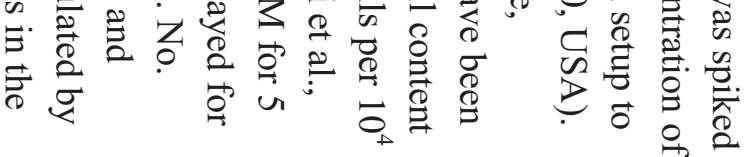


怘芯

芯 芯

$\frac{n}{4}$

$\stackrel{N}{\circ}$

莒

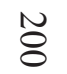

$\vec{b}$

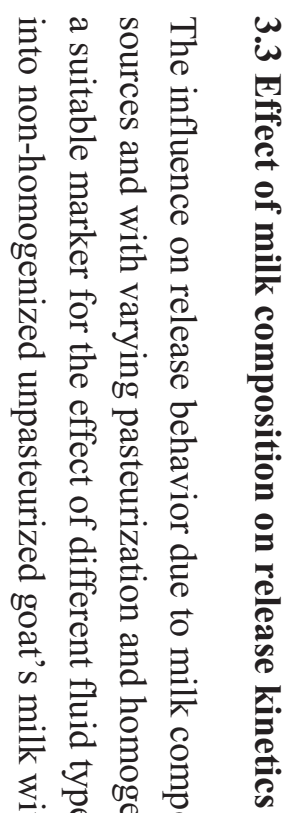

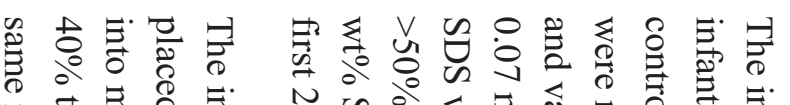

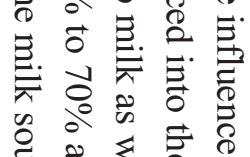

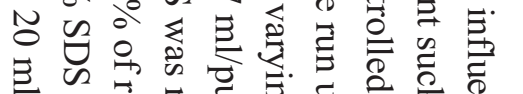

यป讠

w

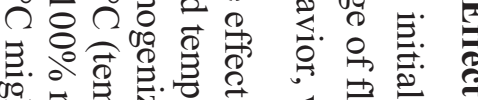

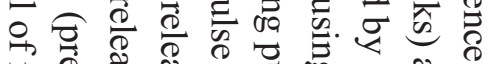

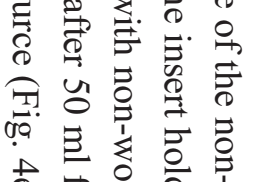
展.

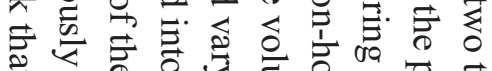

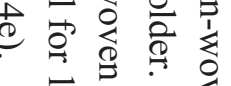
人。ํㅠ용

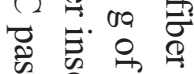

$\stackrel{0}{7}$ 品

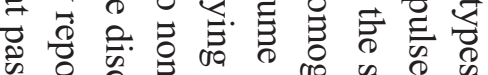

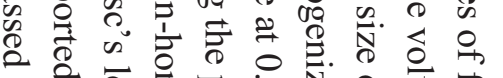

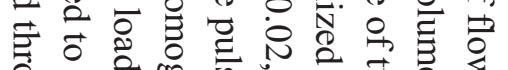

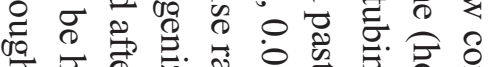

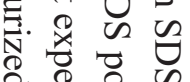

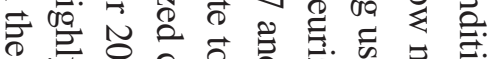
क

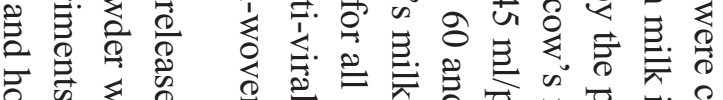
可

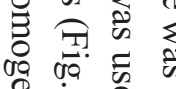

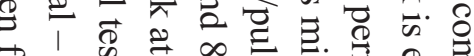
每. 흥 它

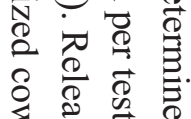

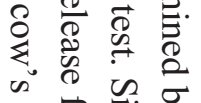

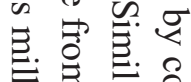

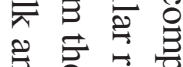
证

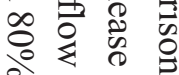

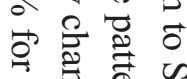

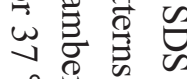

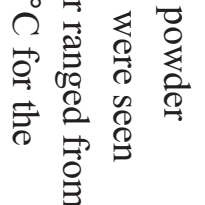

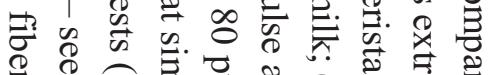

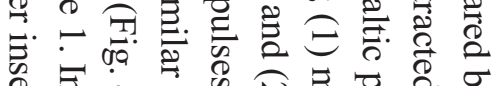

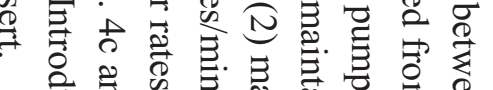

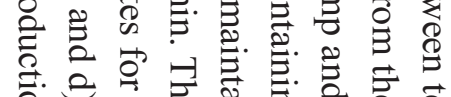

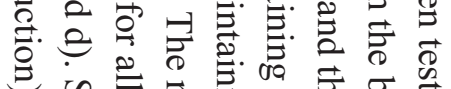

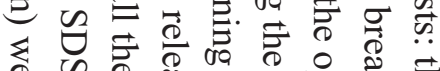

일

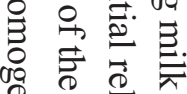

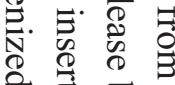

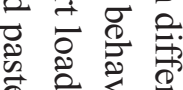
蛋.

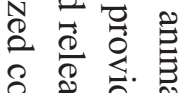

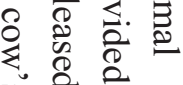

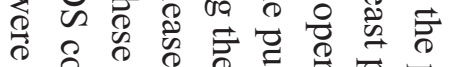
की

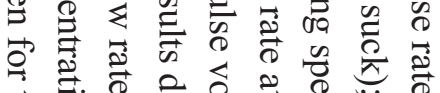

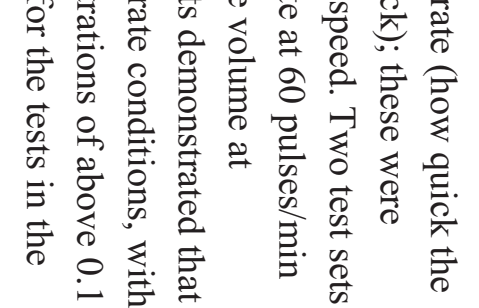

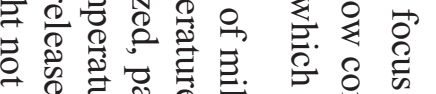

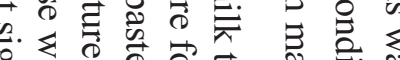
过

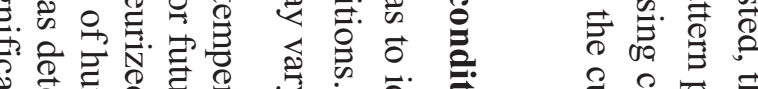

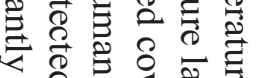
. 상

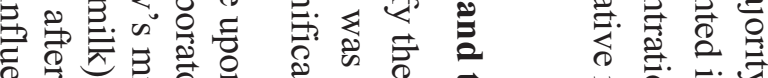

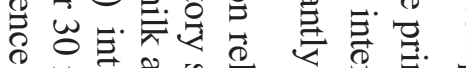

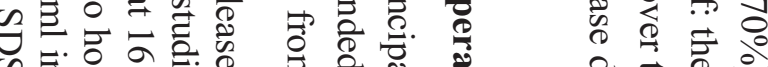

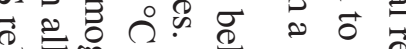

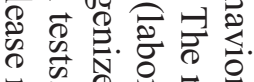
作

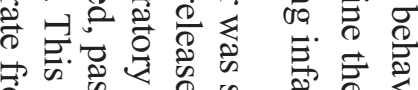

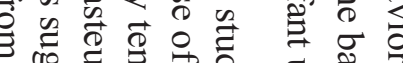

夏

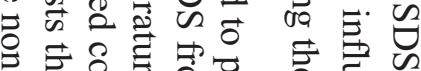

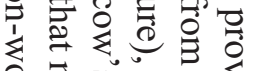

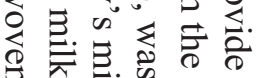
के

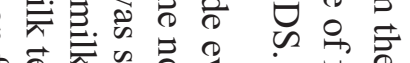

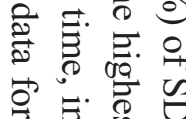

궁

है हैं :

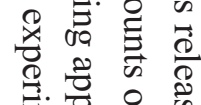

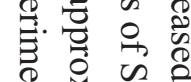

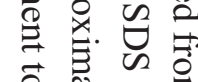

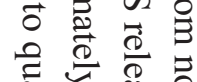

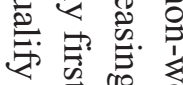
혼.

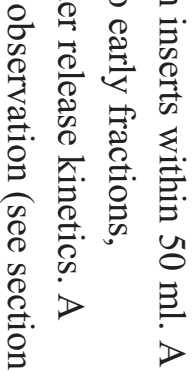

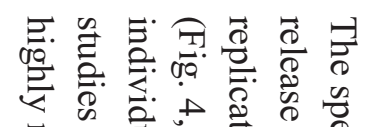

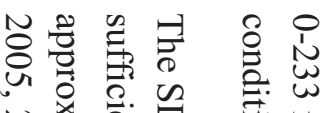

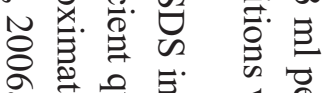
के

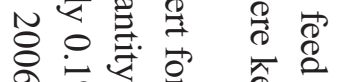

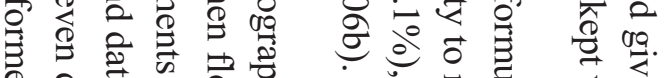

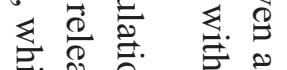

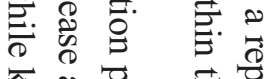

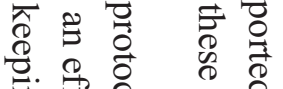

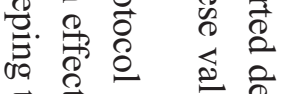

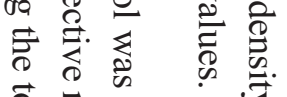

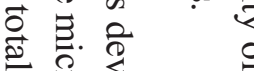
F $\cong$ ठे के के

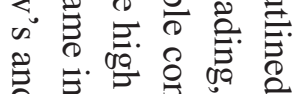

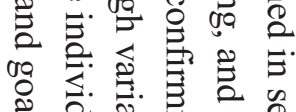

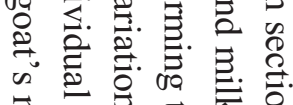

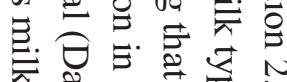

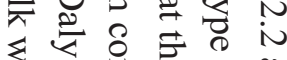
造.

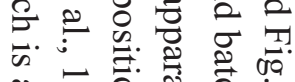

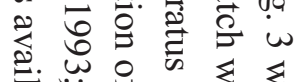

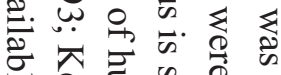

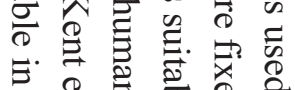

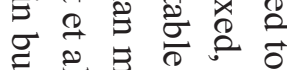

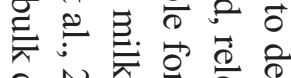

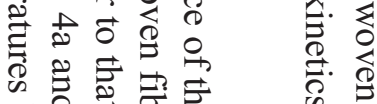
类䛥

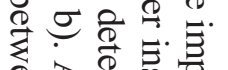

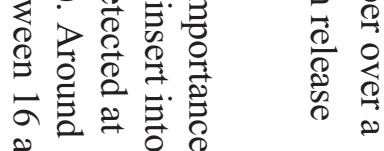

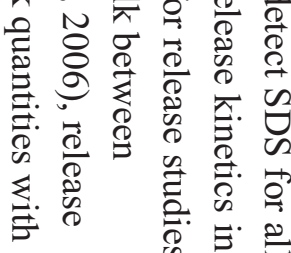
纪客递客

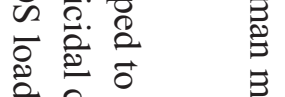
运

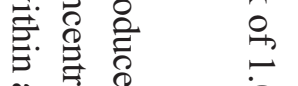

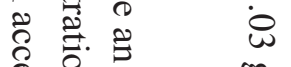

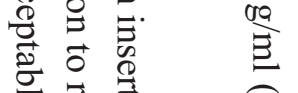

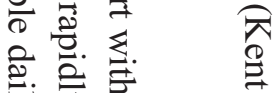

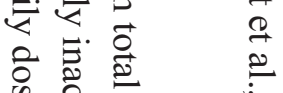

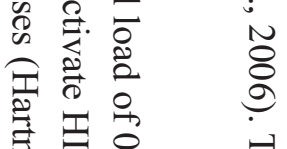

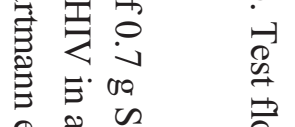

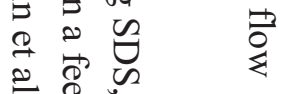

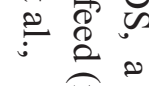




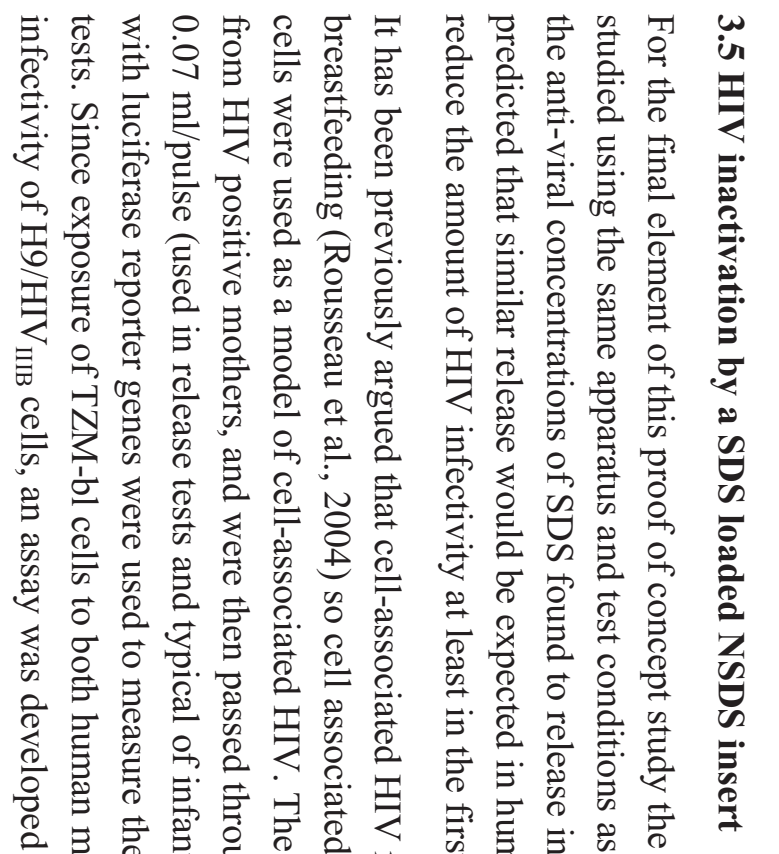

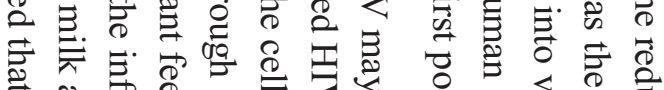

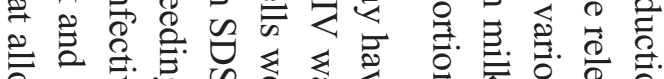

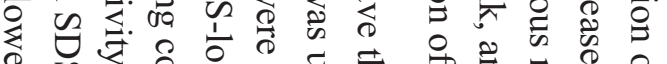

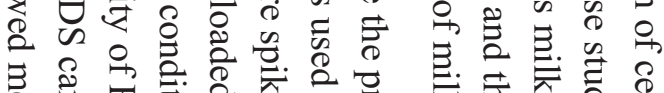
\% 蛋

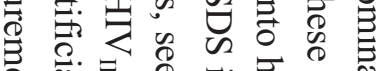

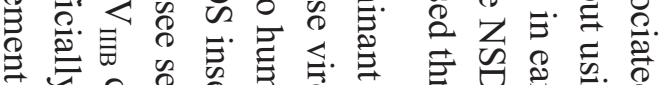

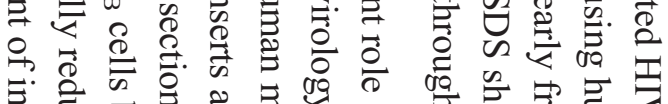

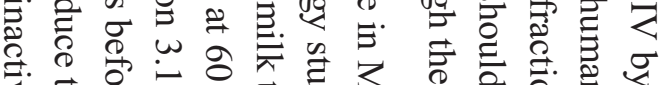
항ㅎㅇ

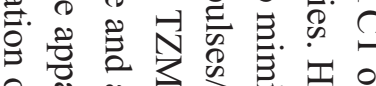

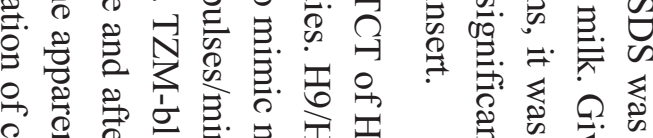

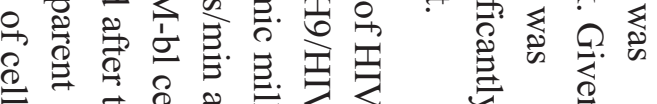

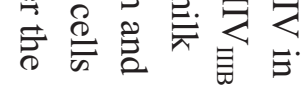

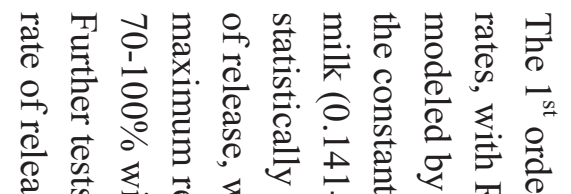

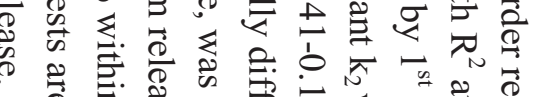
c E. 嗼

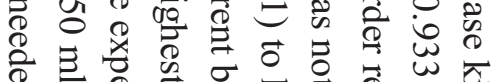

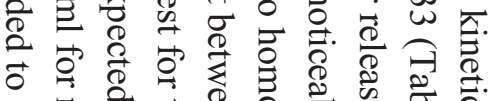

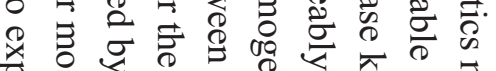

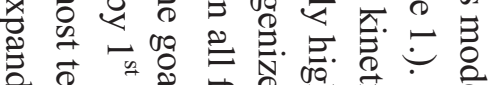

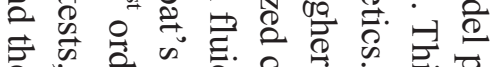

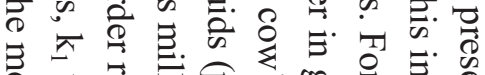

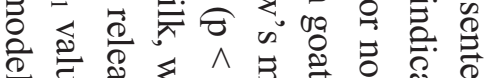

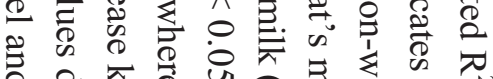

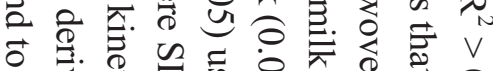

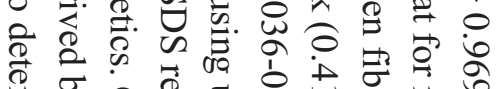
可

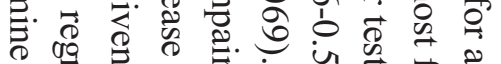

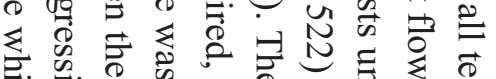
항

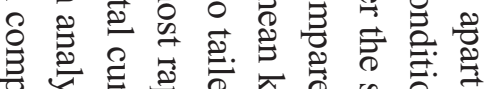

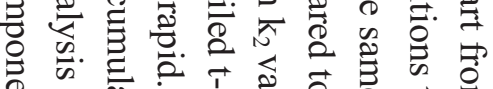

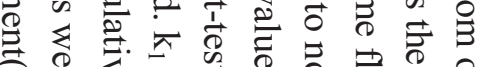

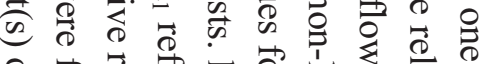

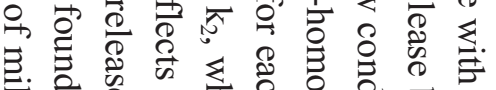

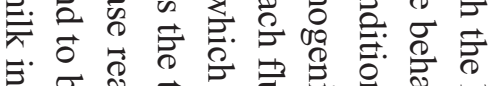

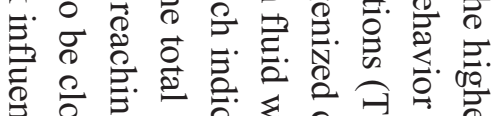

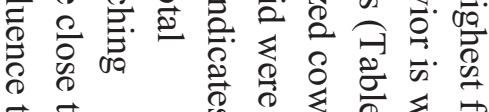

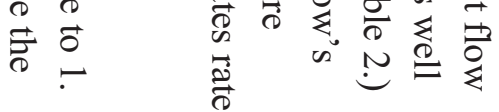

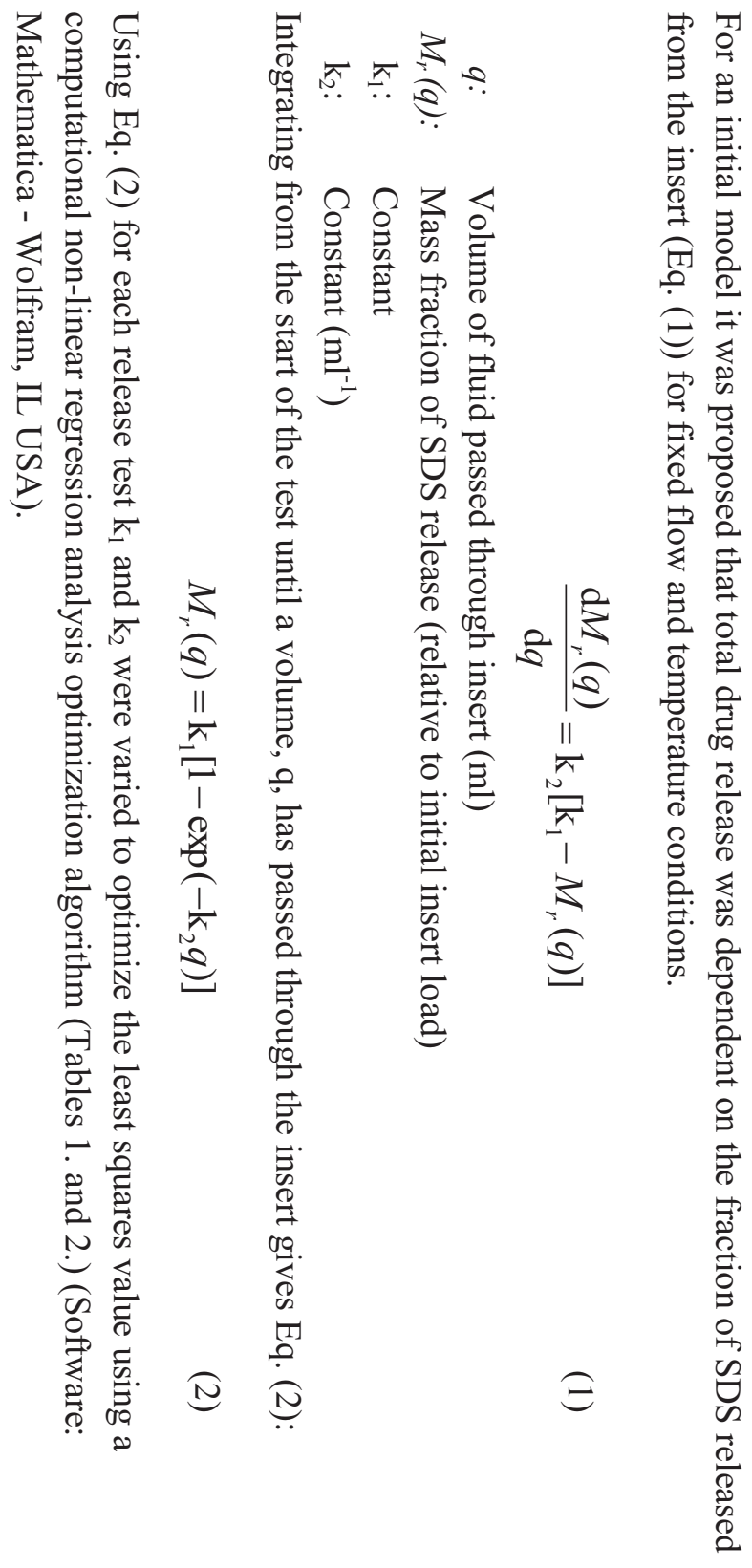




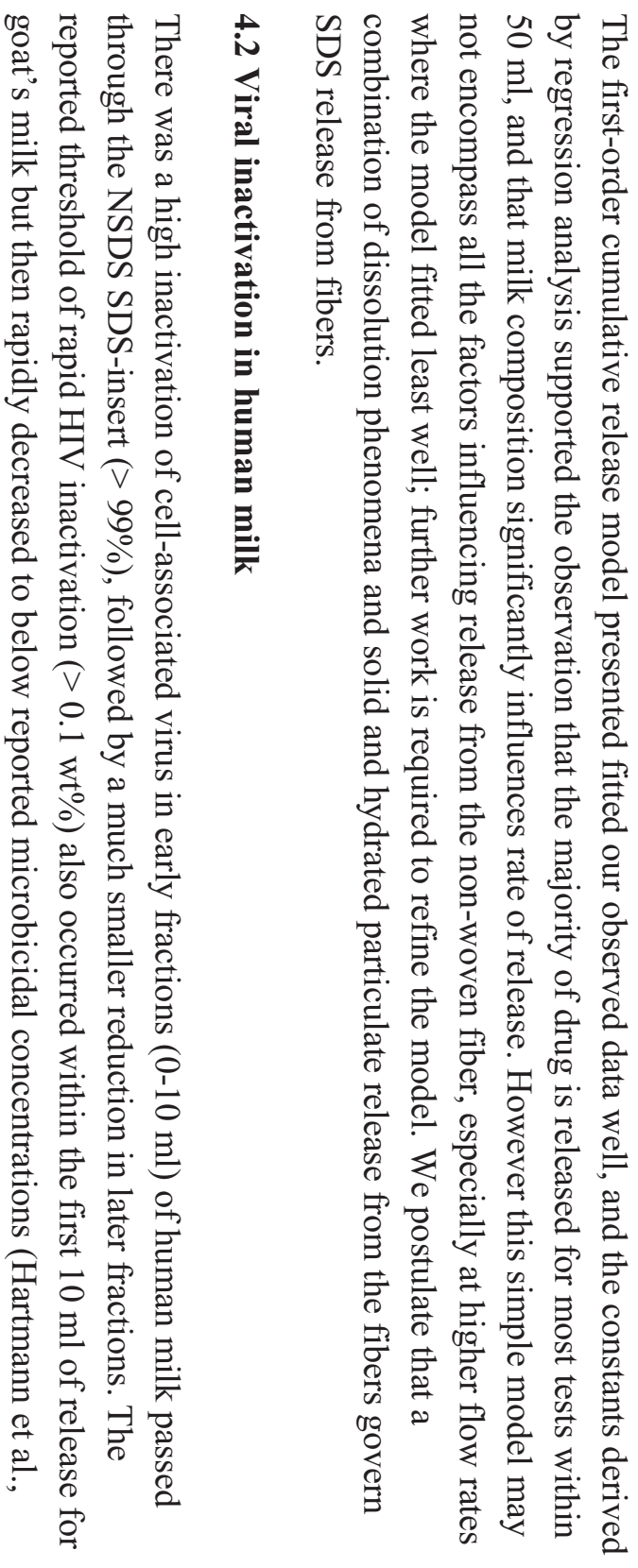

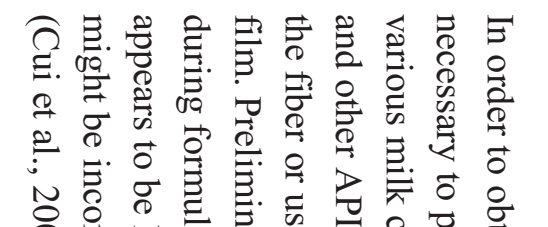

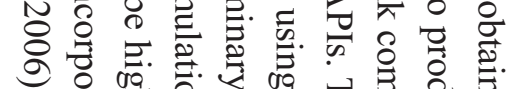

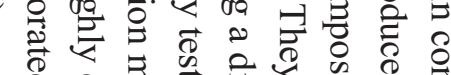

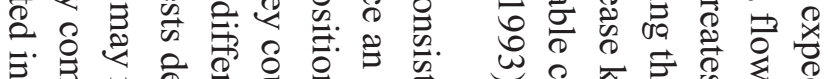

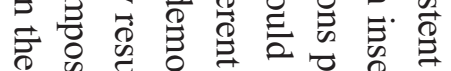

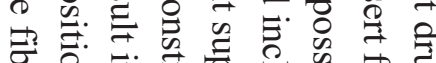
年

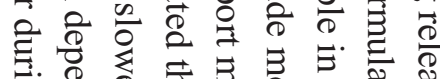

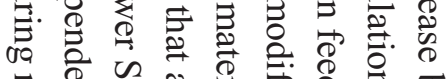

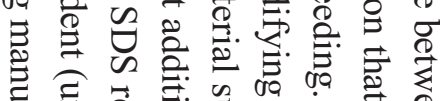

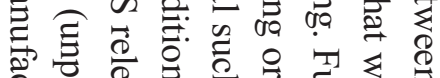

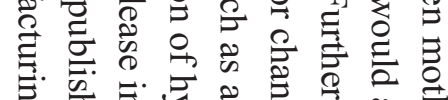

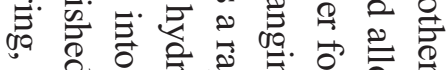

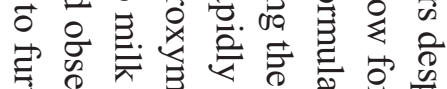

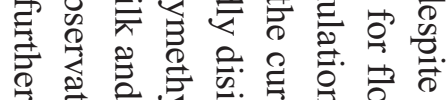

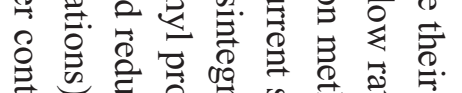

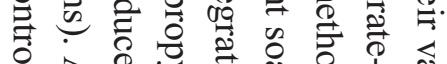

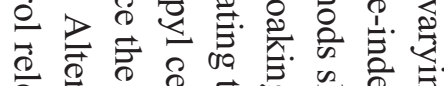

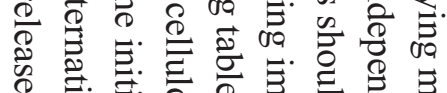

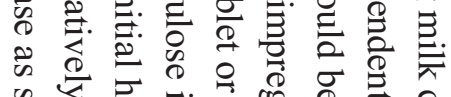

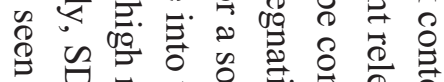

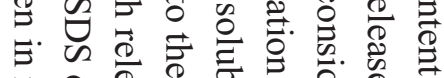

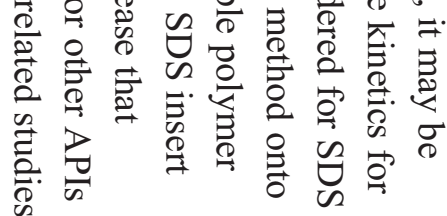

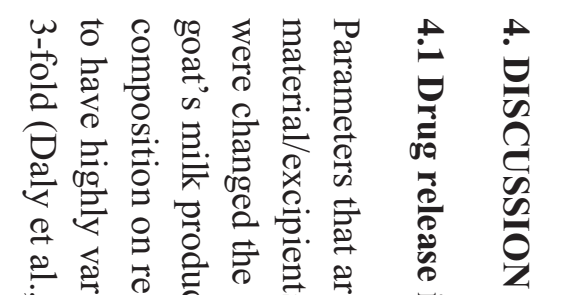

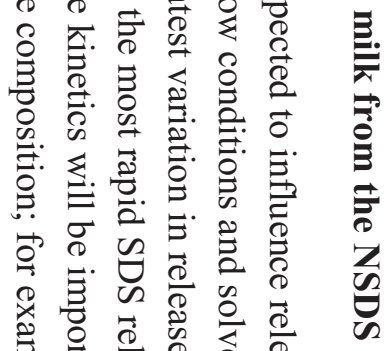

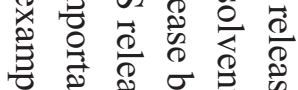

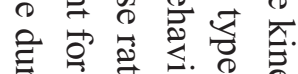
ज.

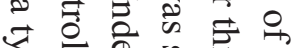

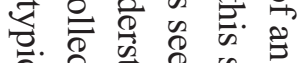

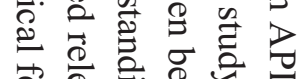

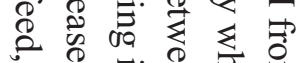
के E. E.

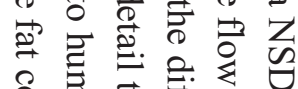

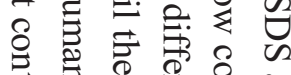

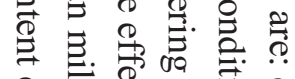

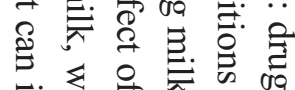
‥ 这.

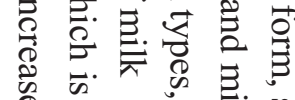

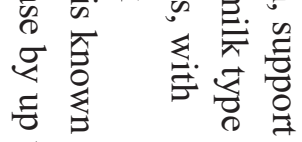

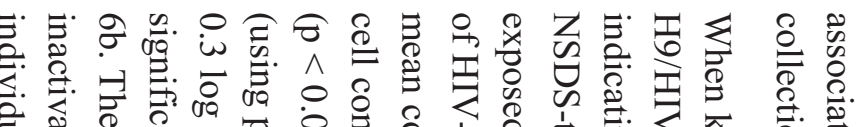

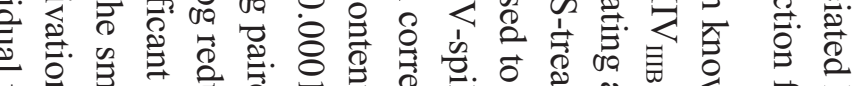

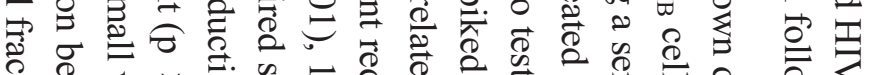

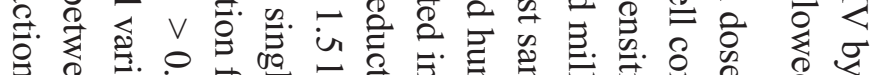

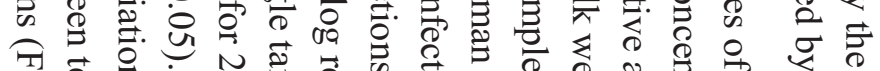

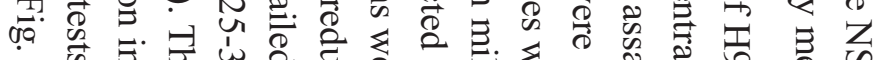

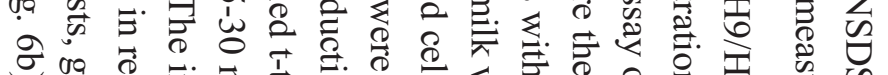

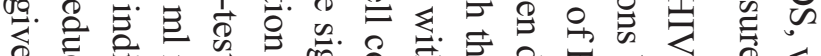

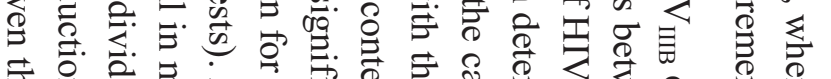

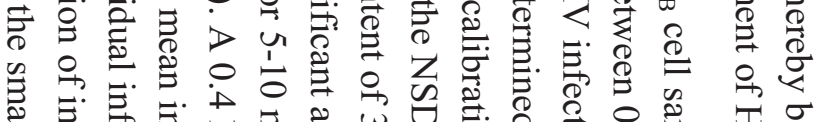

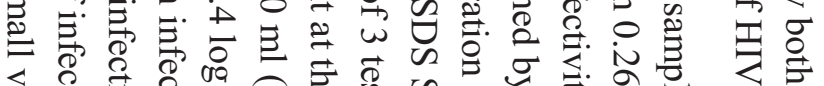

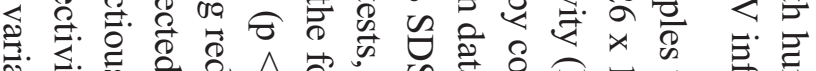

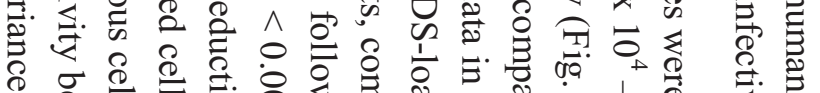

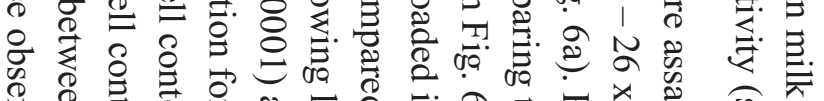

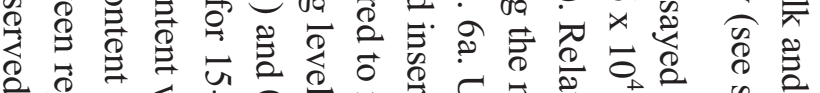

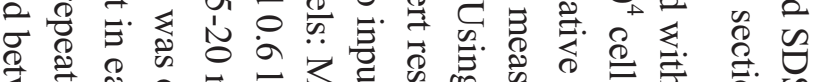

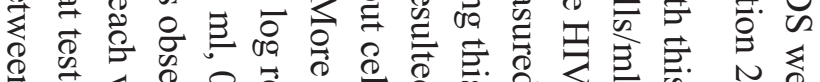

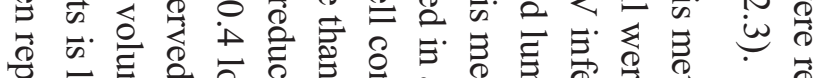

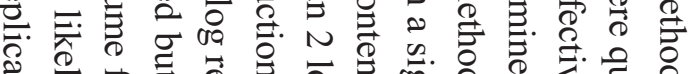

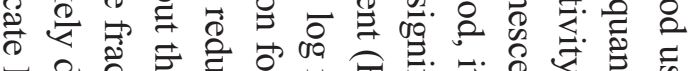

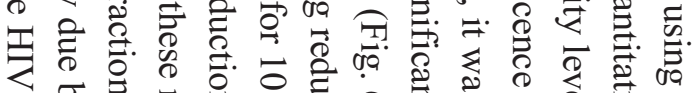

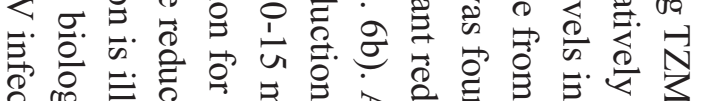

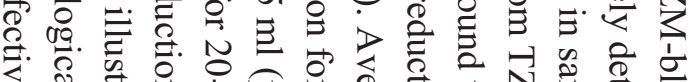

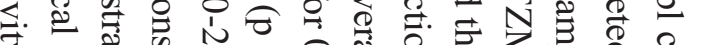

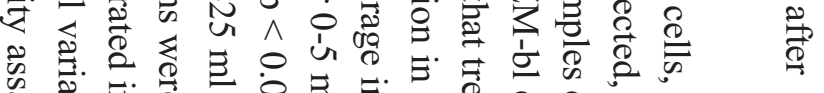

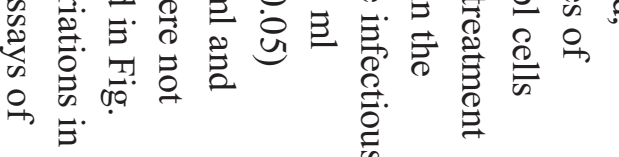




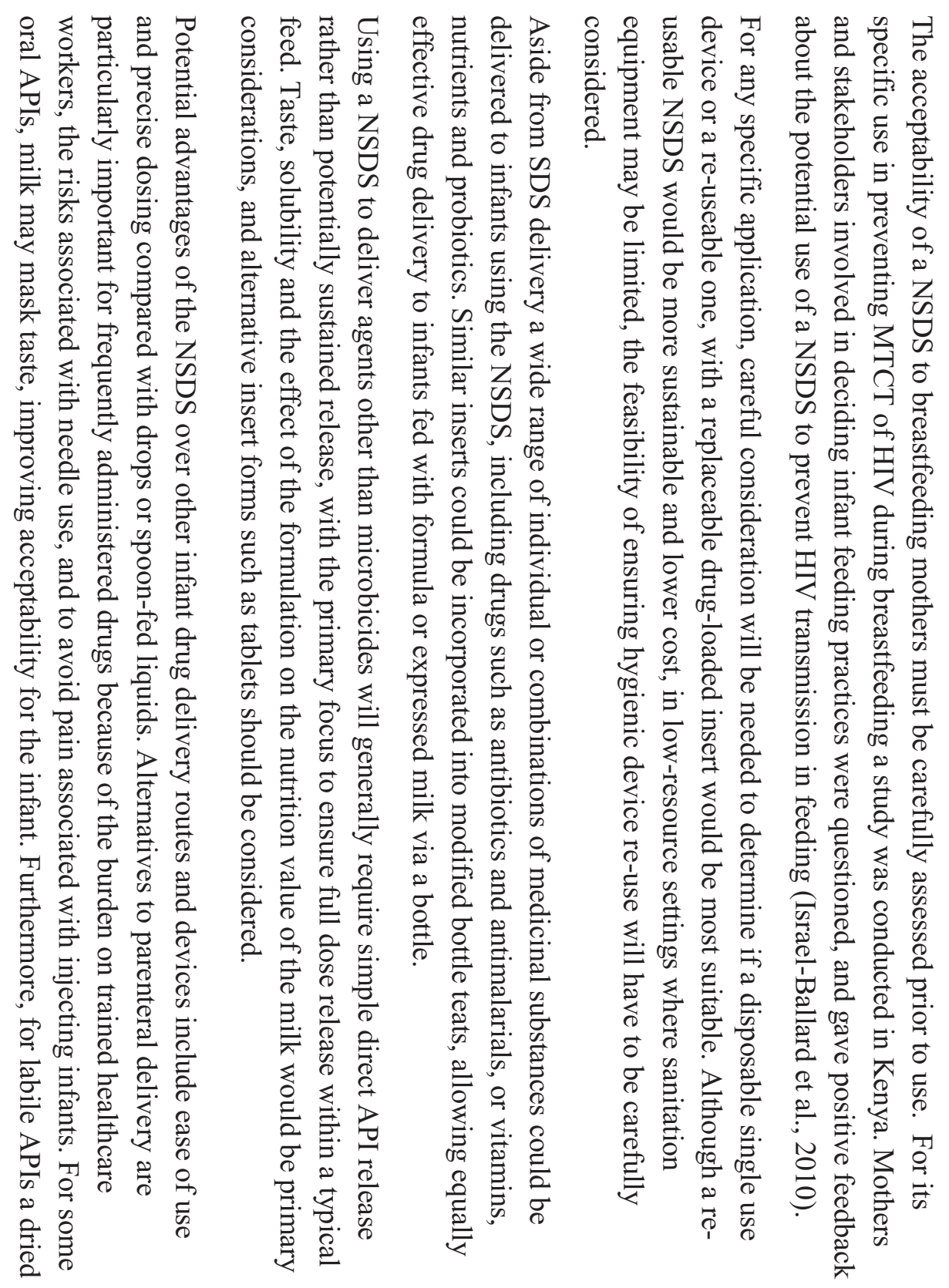

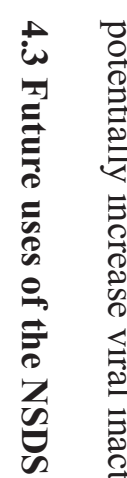

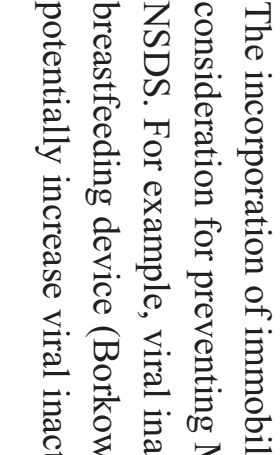

政.

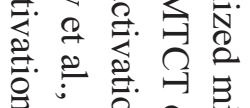

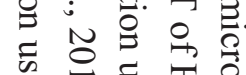

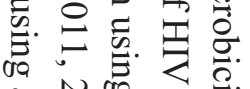

Z

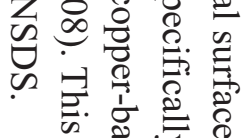

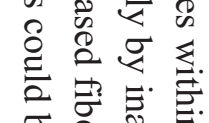

言总

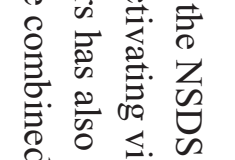

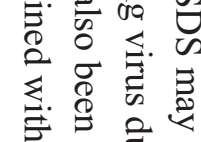

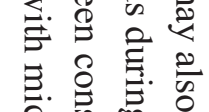

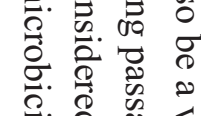

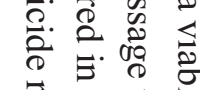

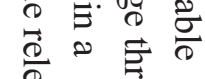

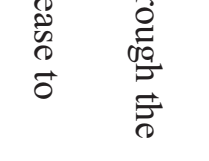

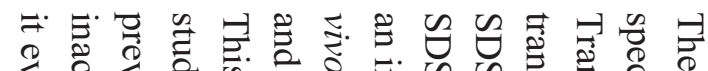

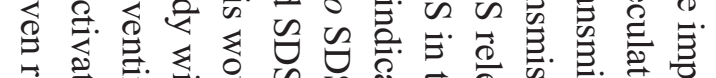

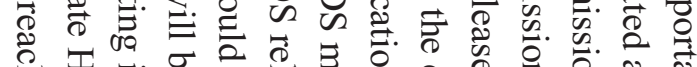

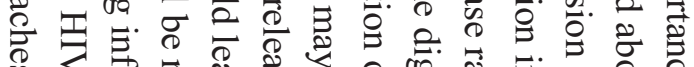

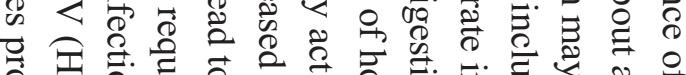

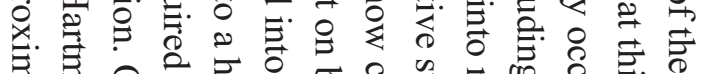

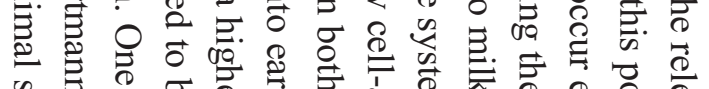

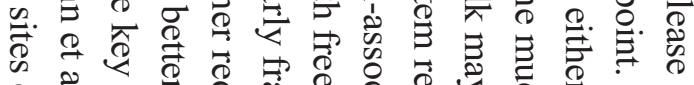

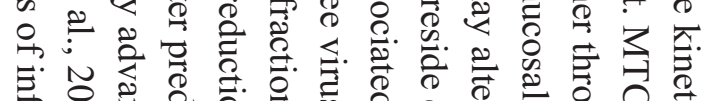

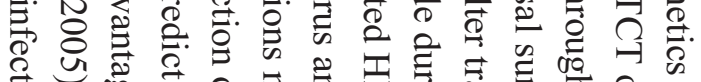

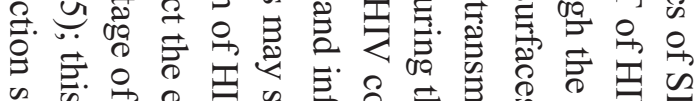

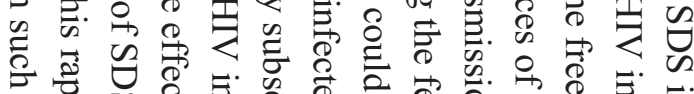
क के

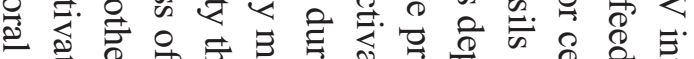

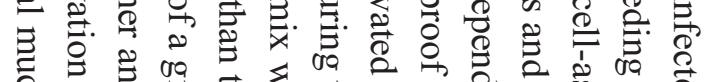

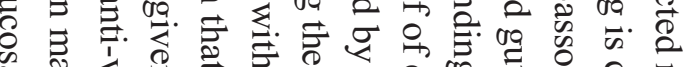

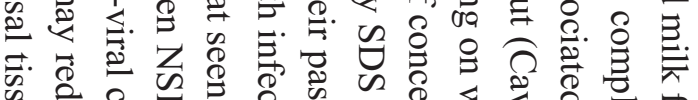
है ᄋ

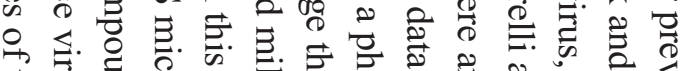

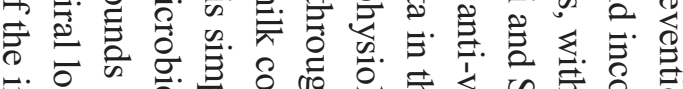

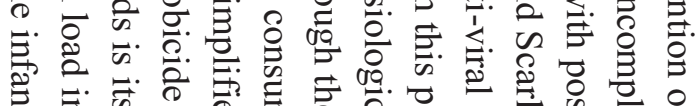

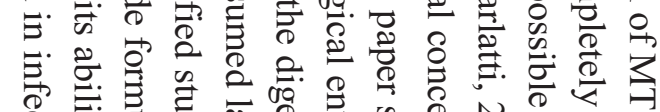

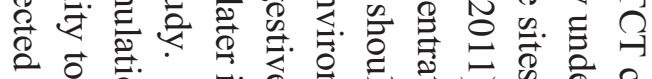

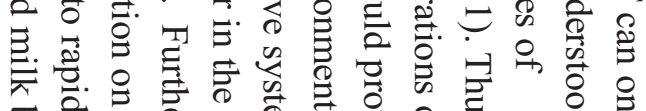

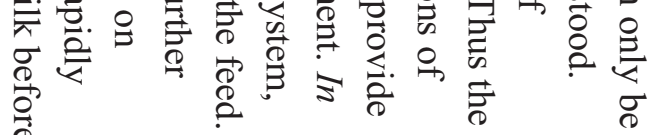

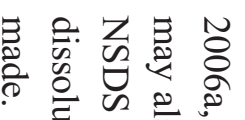
ㄷ. $\overrightarrow{0}$ के 造 兘 : \&

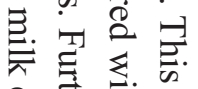
\& $\overline{0}$ 石 层

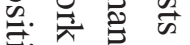
官完弮

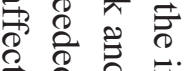
के 2 ह

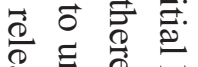
递 त्र. 물 을. क 总 융 ह

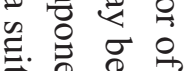

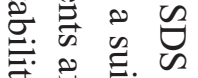
류율 i क्ष

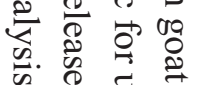

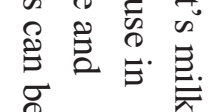




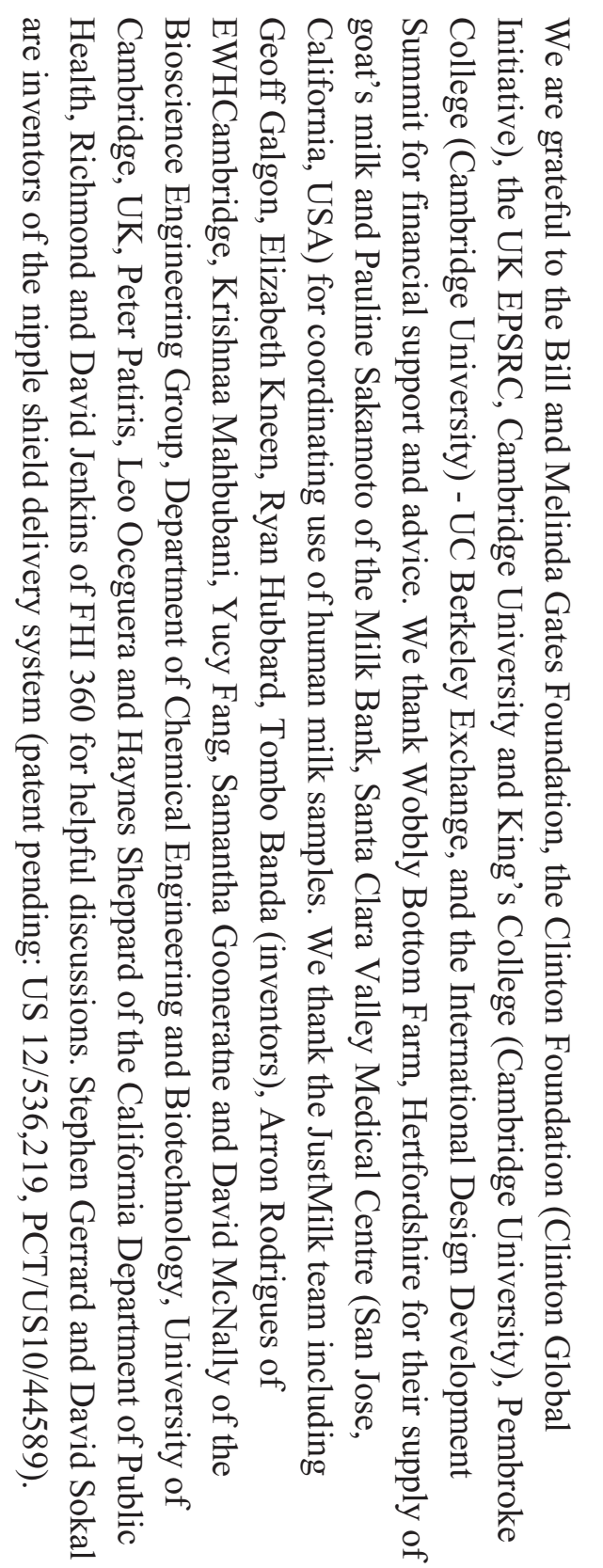

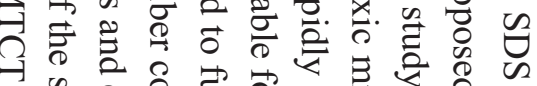

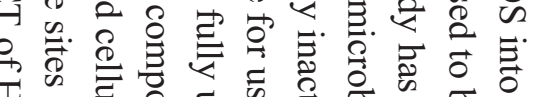

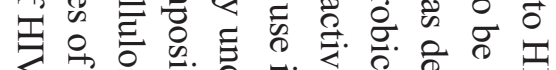

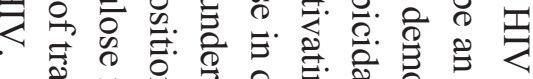

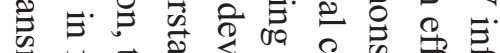

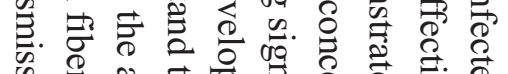

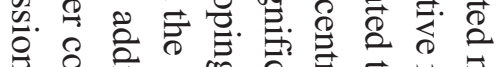

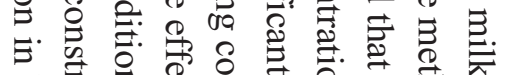

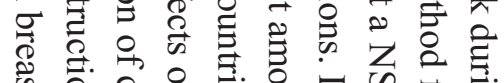

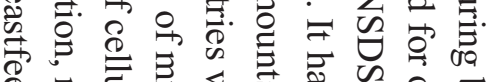

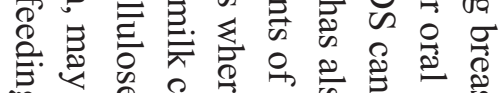

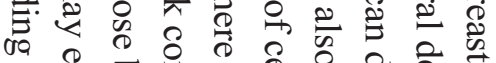

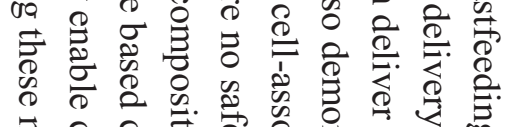

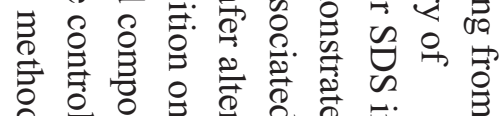

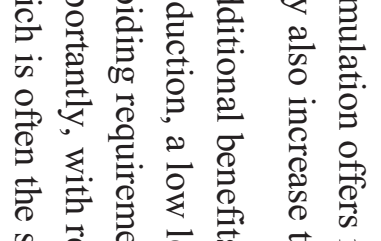
唡 承 7 둥

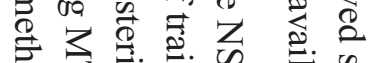

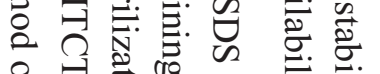
웅 물

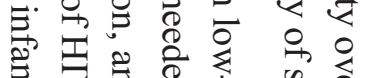

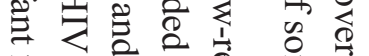

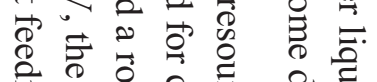

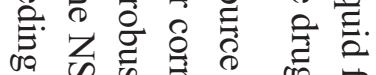

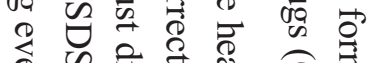
@

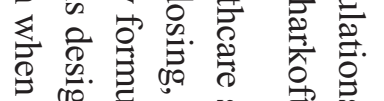

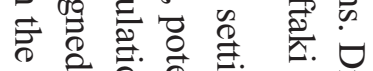

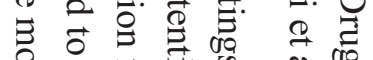
알 它.

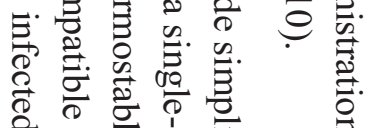

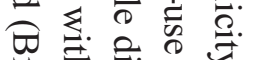

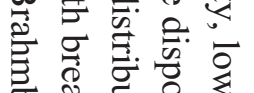

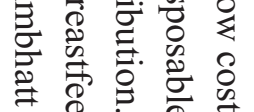

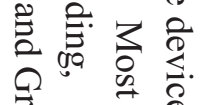




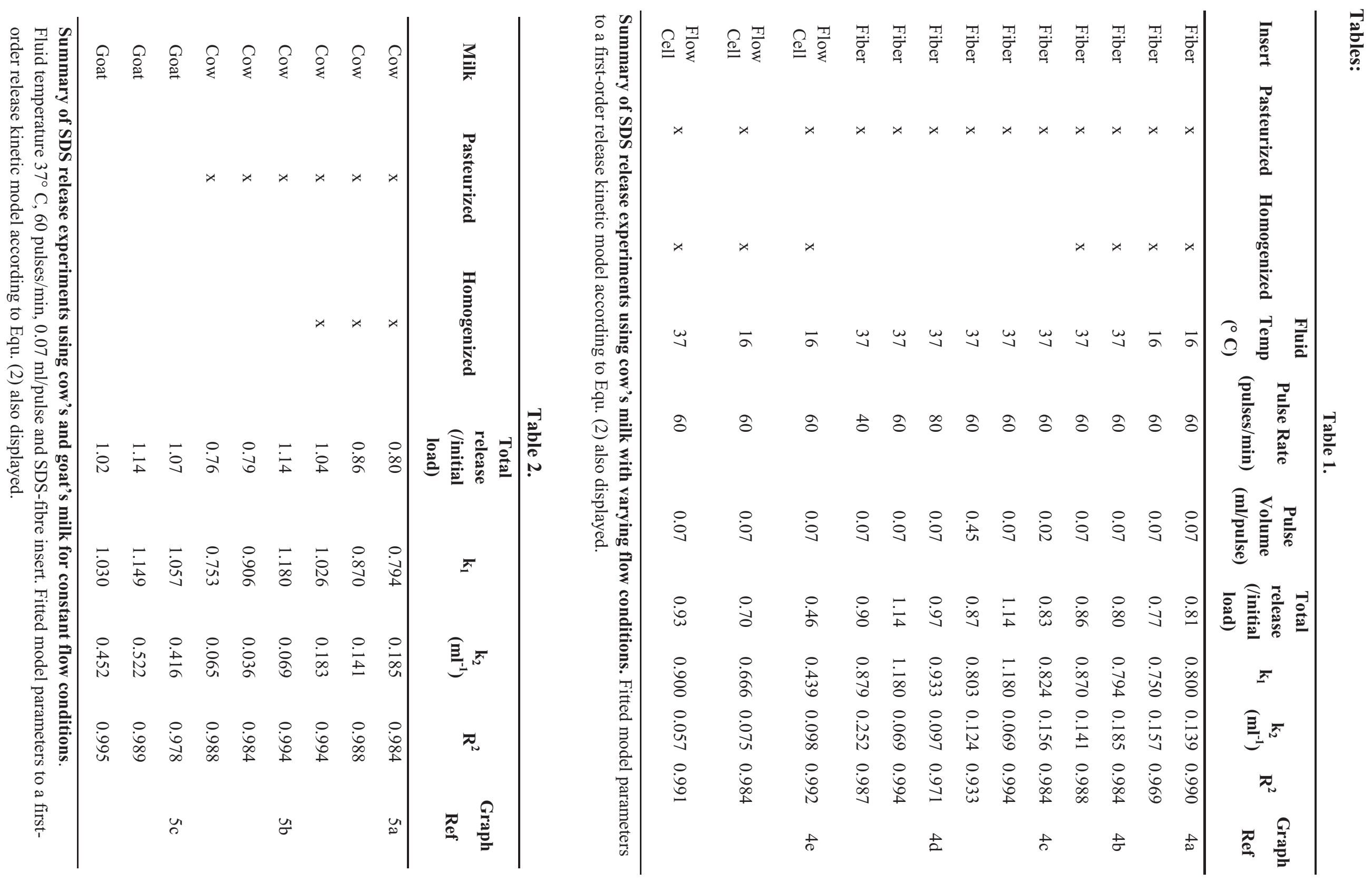




\section{索}

吉

志

吉

芯

怘

荅

志

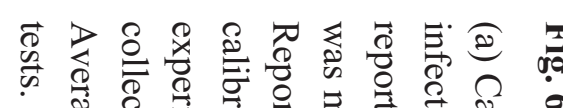

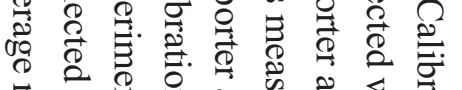

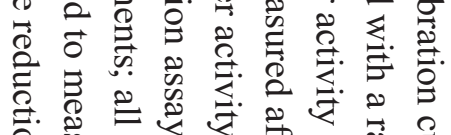

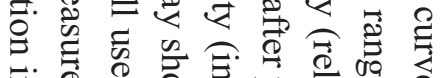

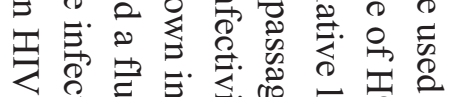

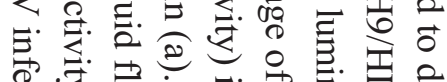
일

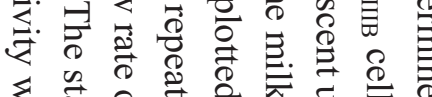

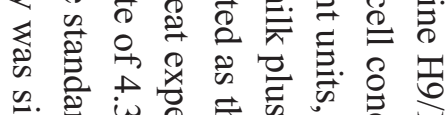

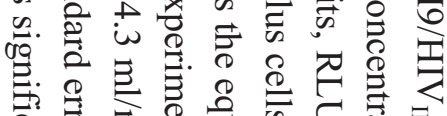

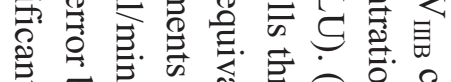

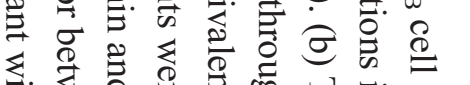

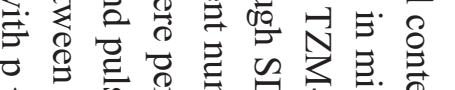
人 $\overrightarrow{0}$ 要

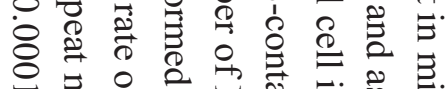
政 *

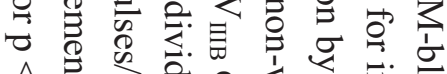

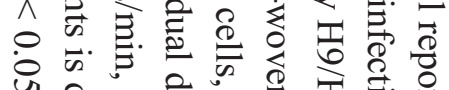

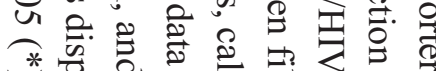
문

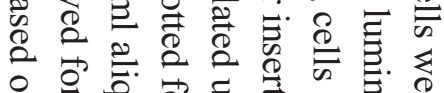

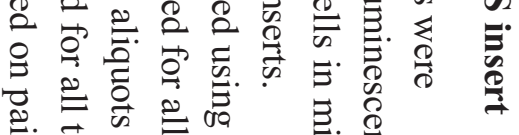
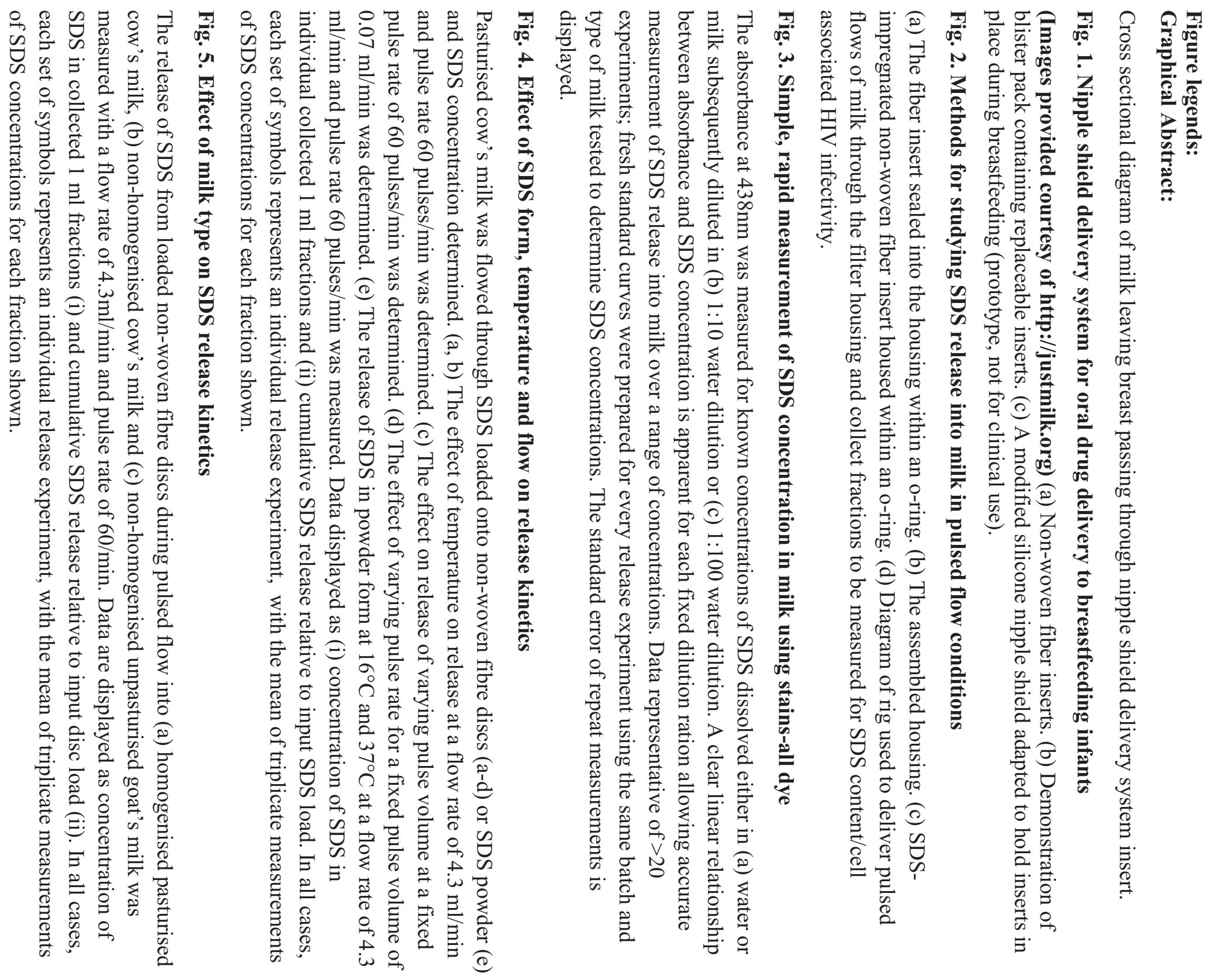

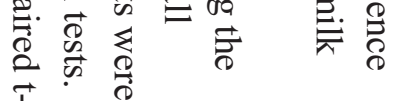

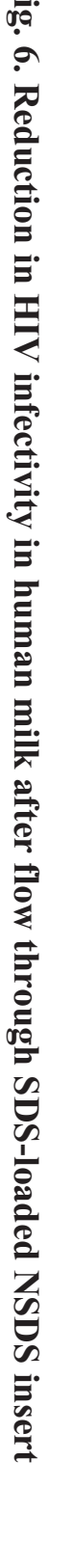




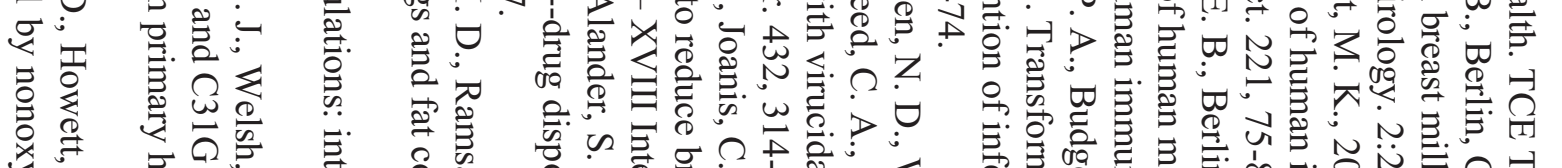

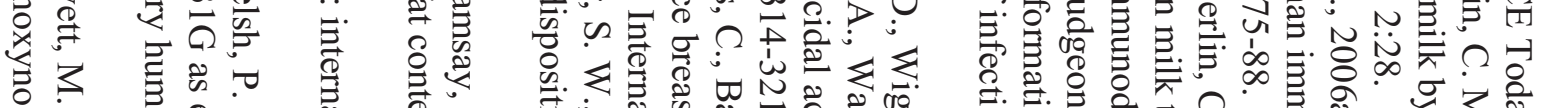

它芟

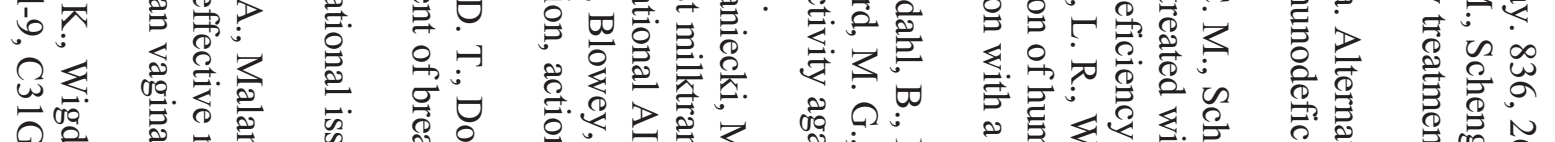

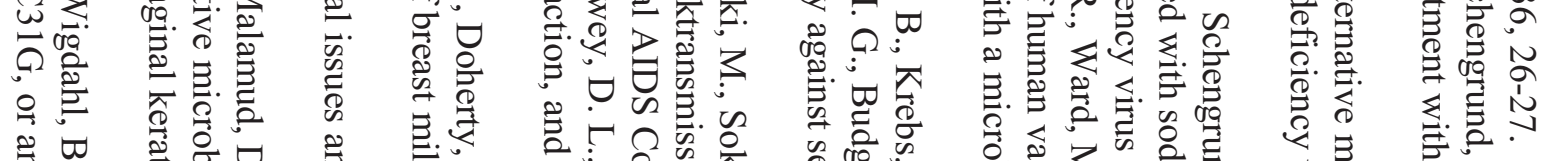

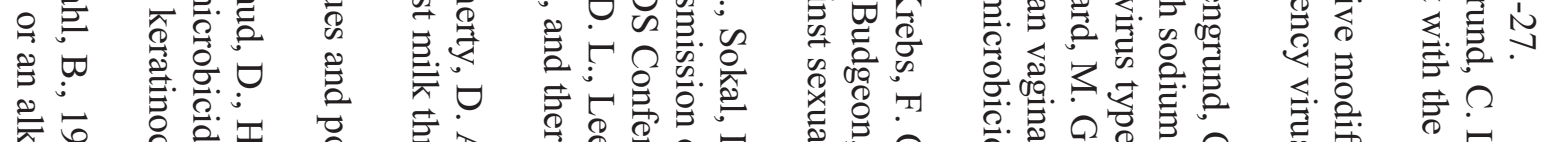

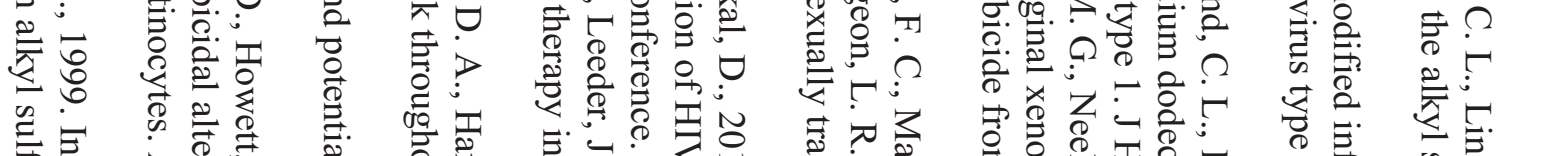

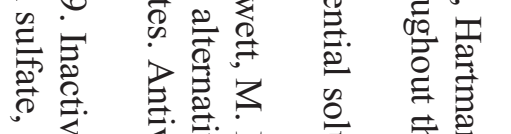

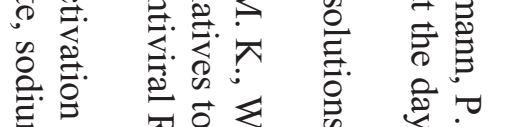

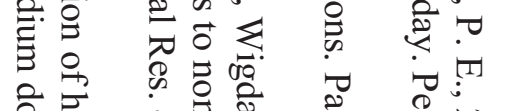

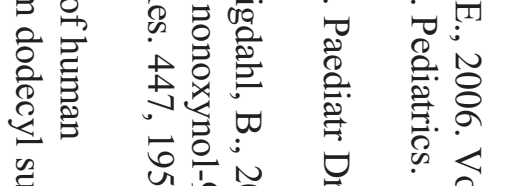

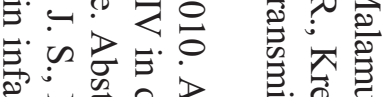

졸 줄 궁

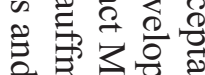

突.

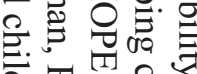

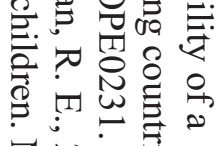

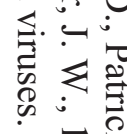

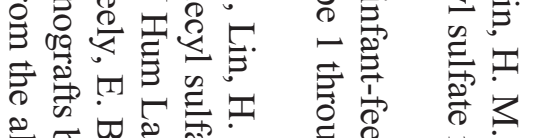

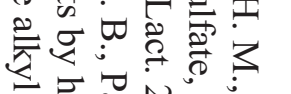

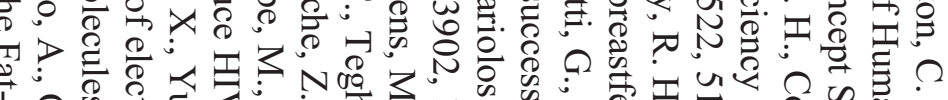

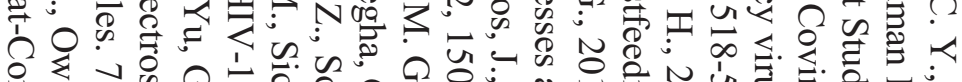

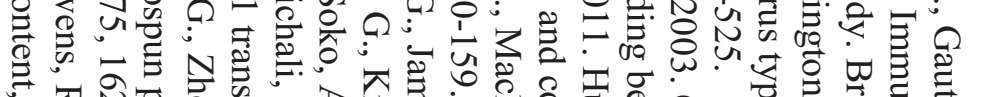

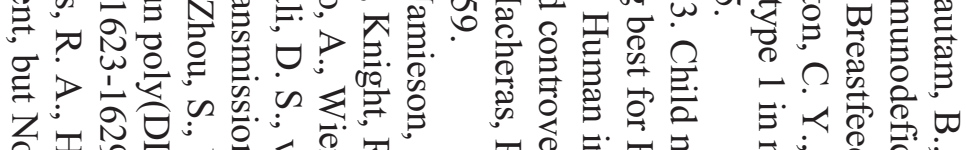

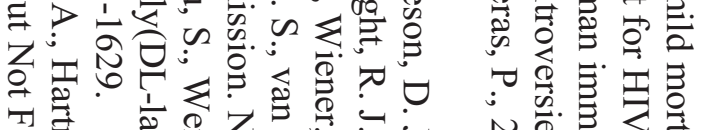

蛋言

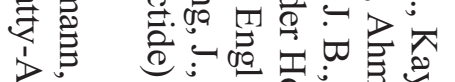

(.)

人it

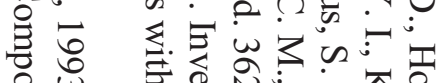

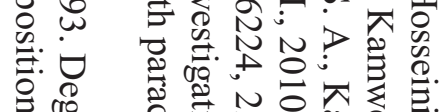

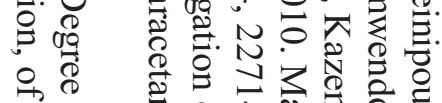

承

일.

나유

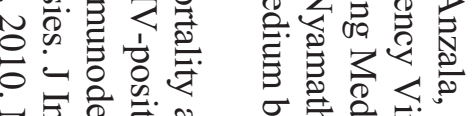

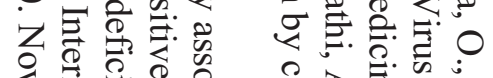

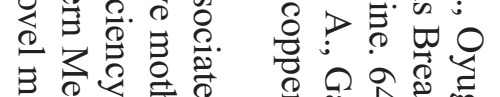

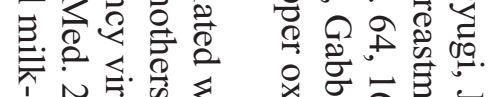

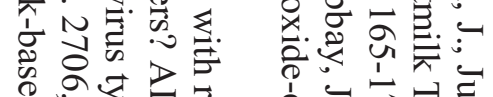

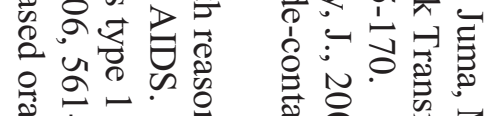

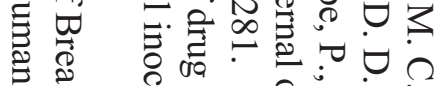

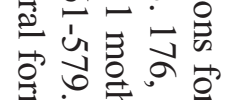

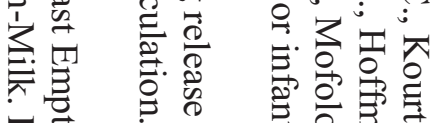

获氠.

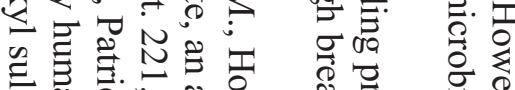

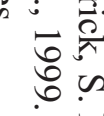

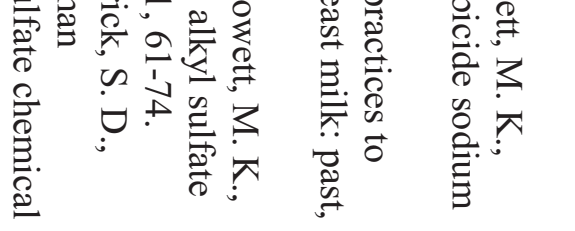

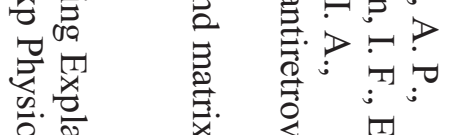

뉼.

央

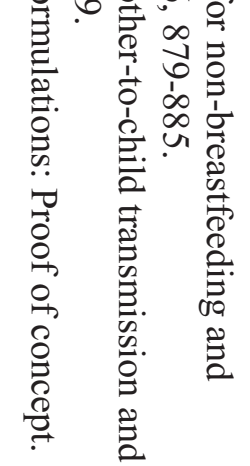

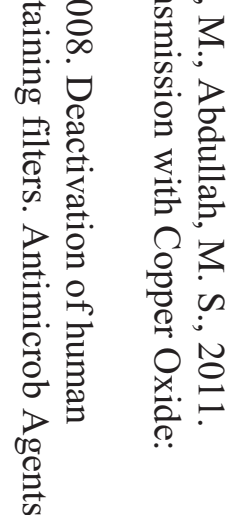




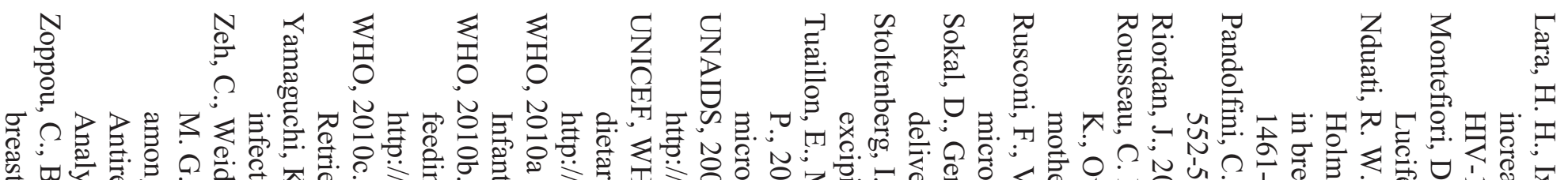

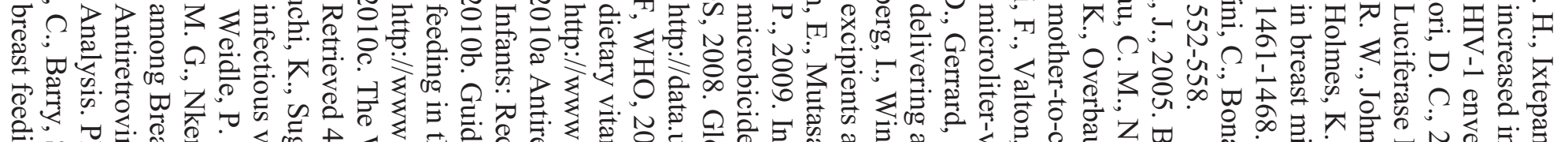

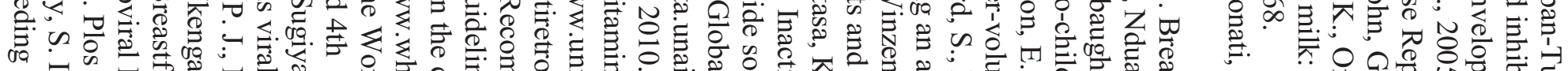

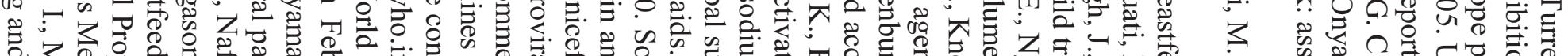

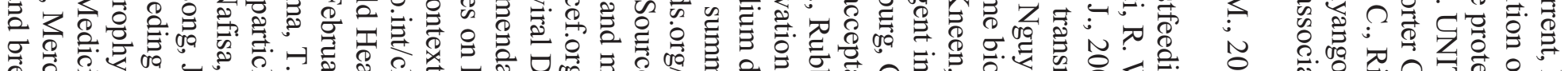

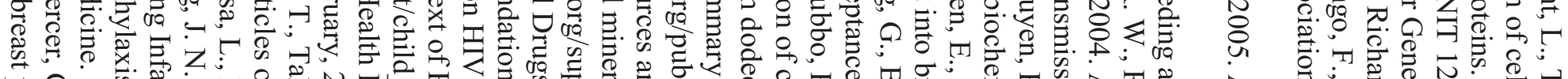

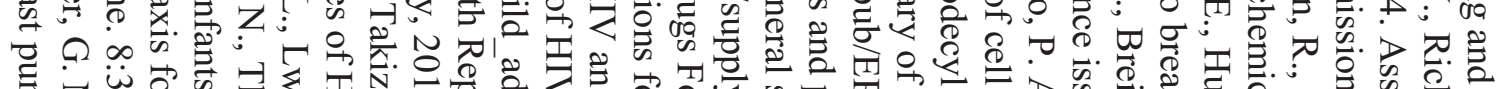

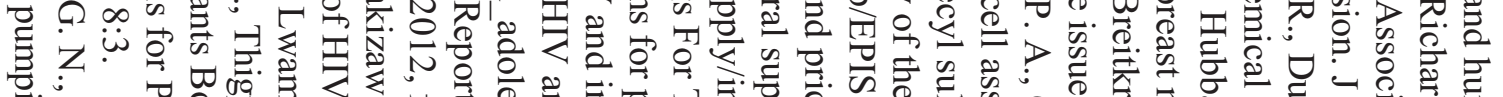

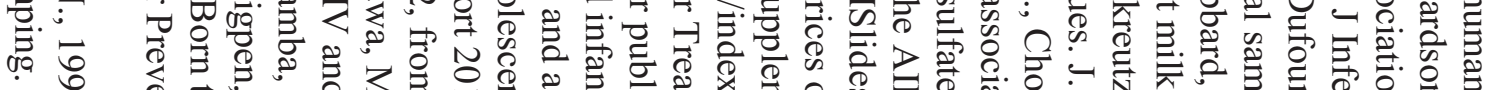
떠

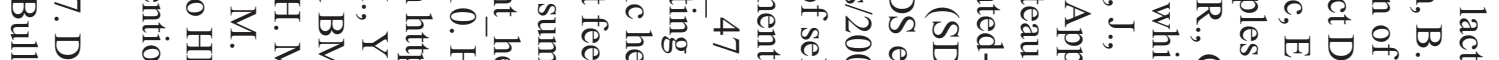

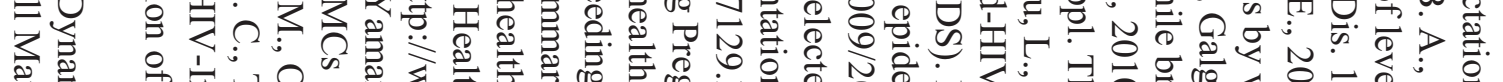

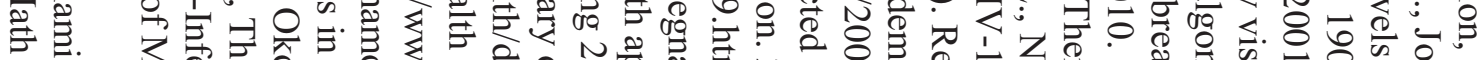

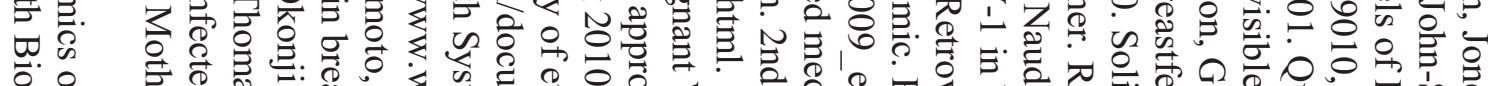

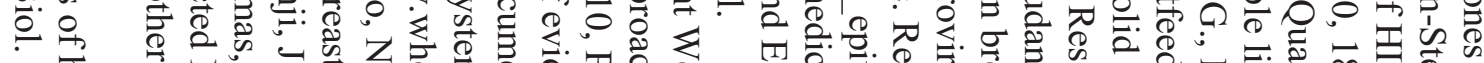

识屋

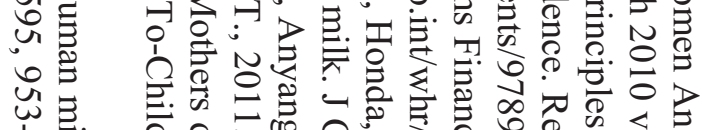

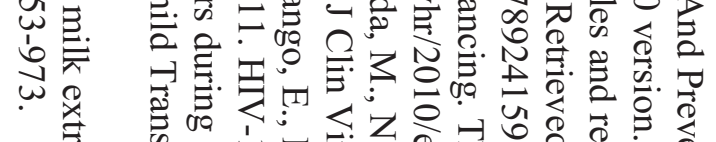

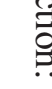

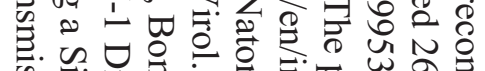

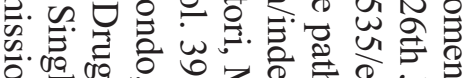
$>$
1

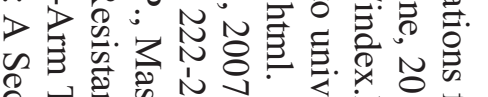

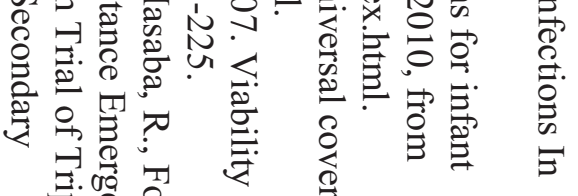

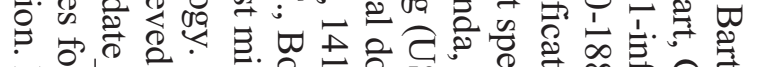

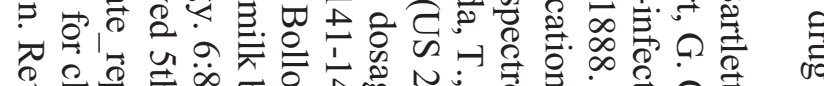

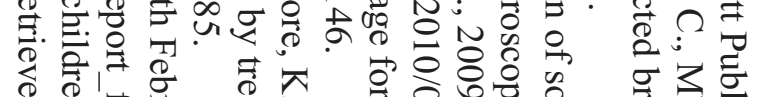

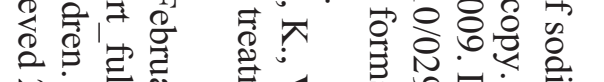

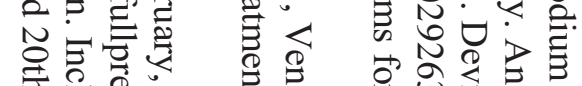

$$
\text { (n) }
$$

尺

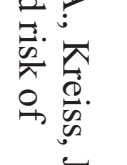




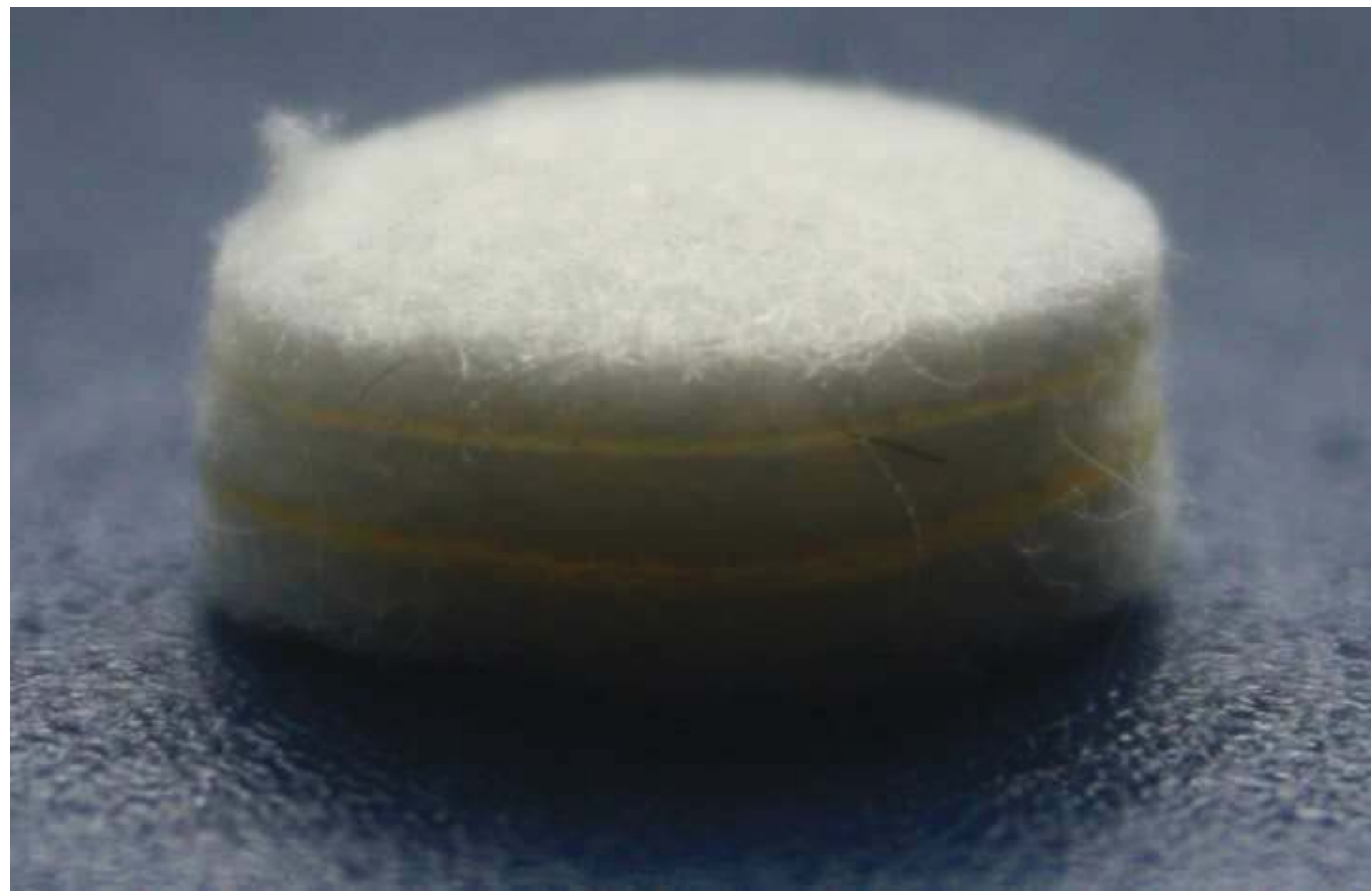




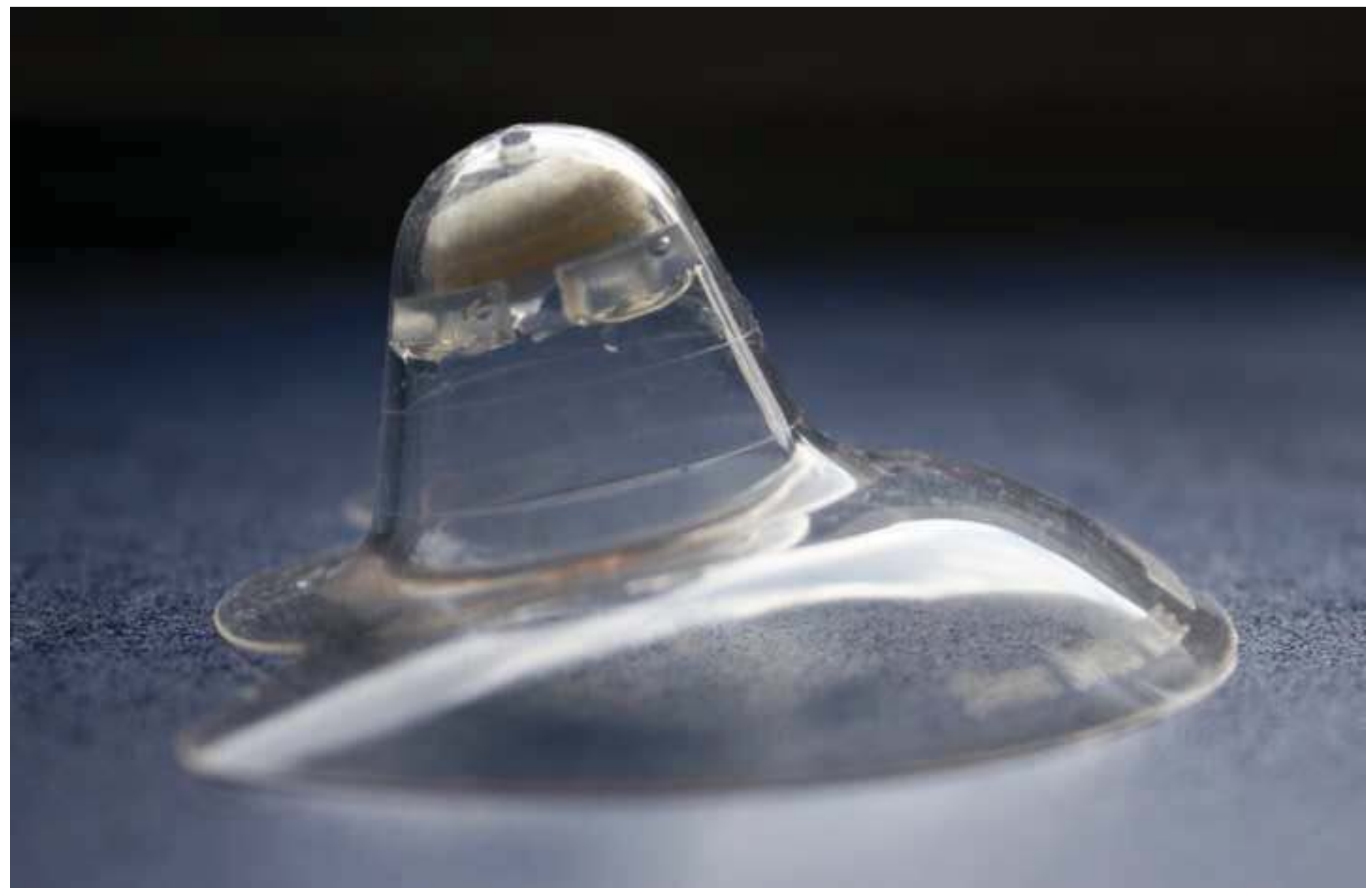




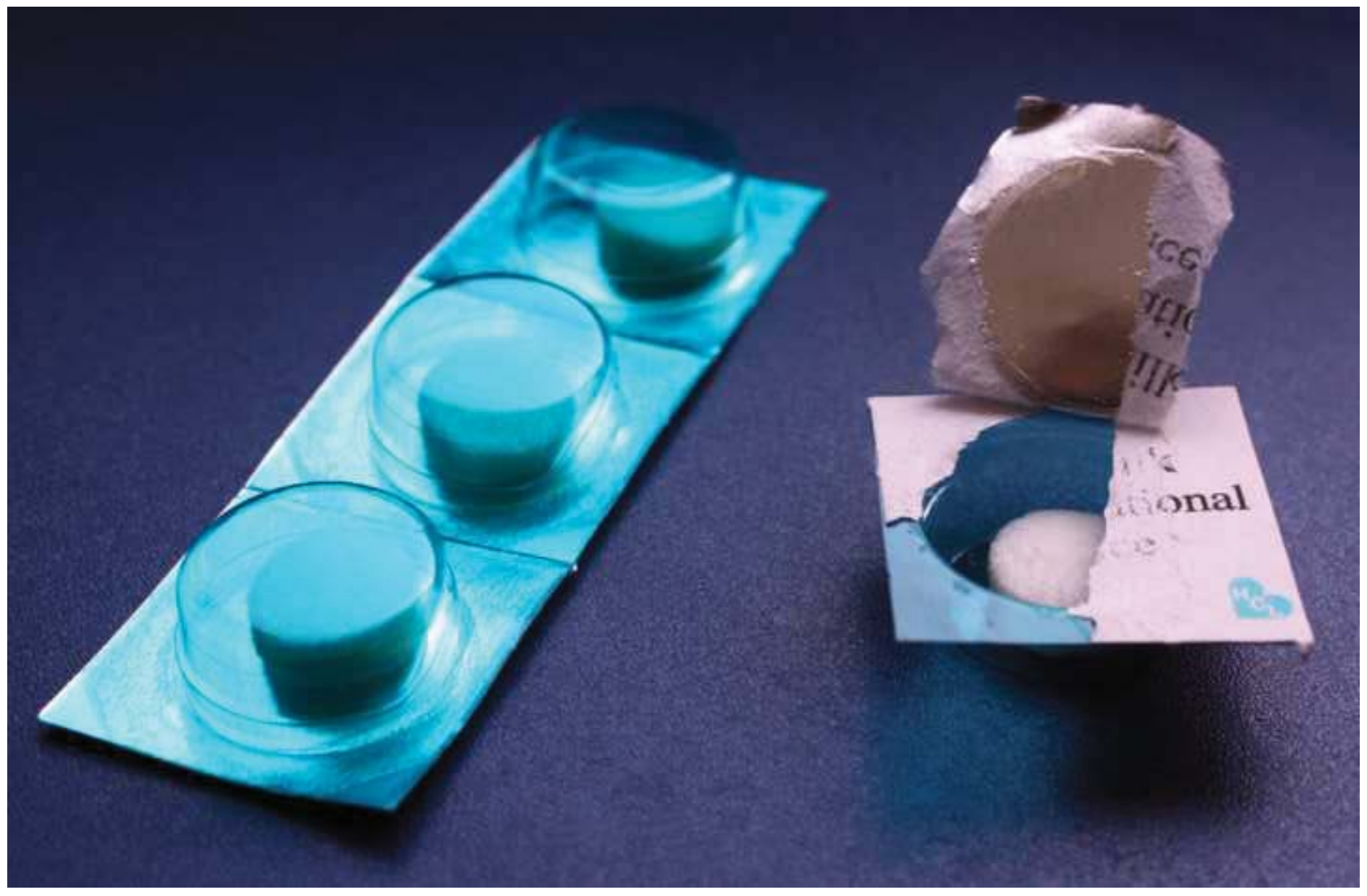




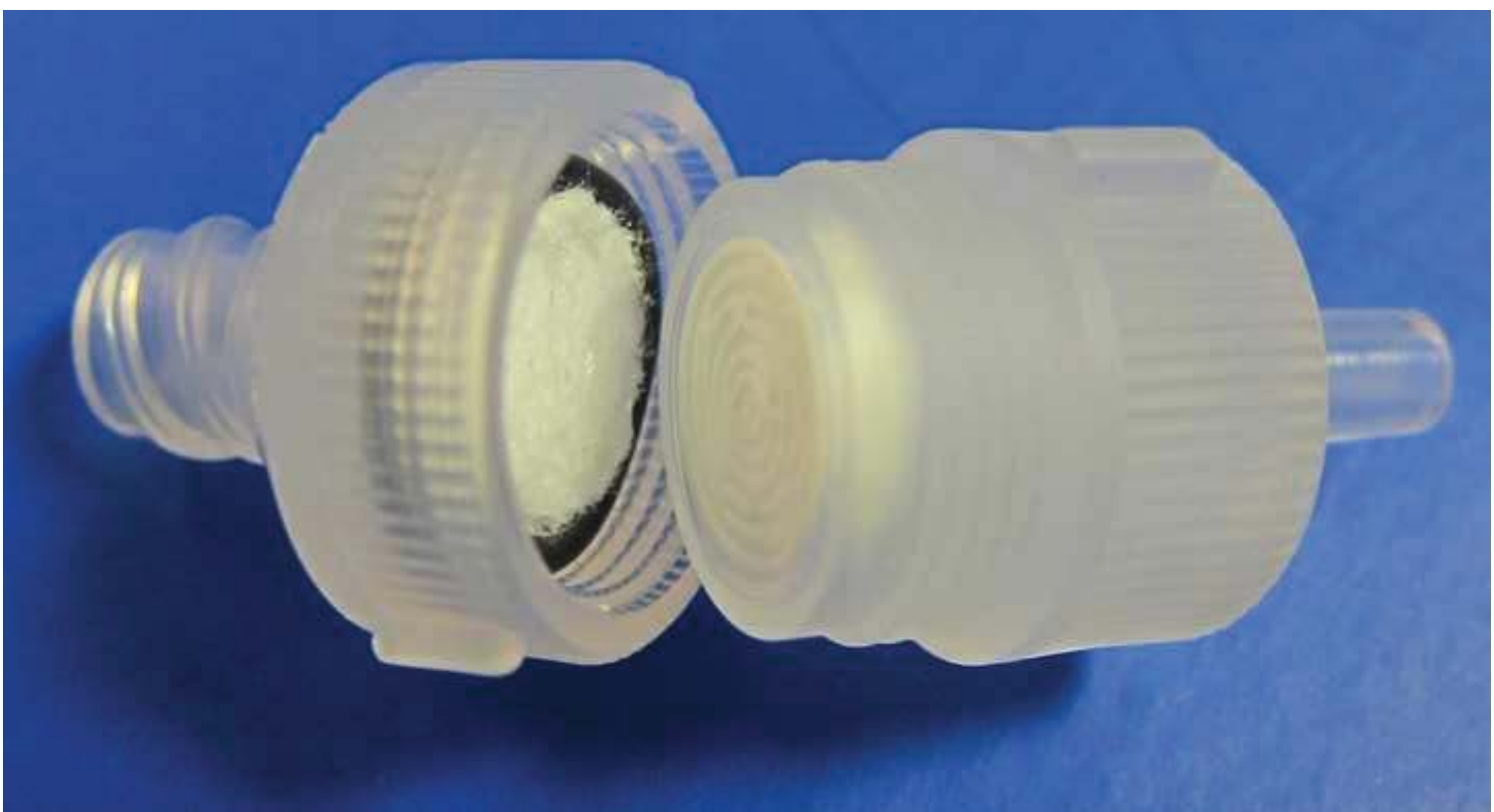




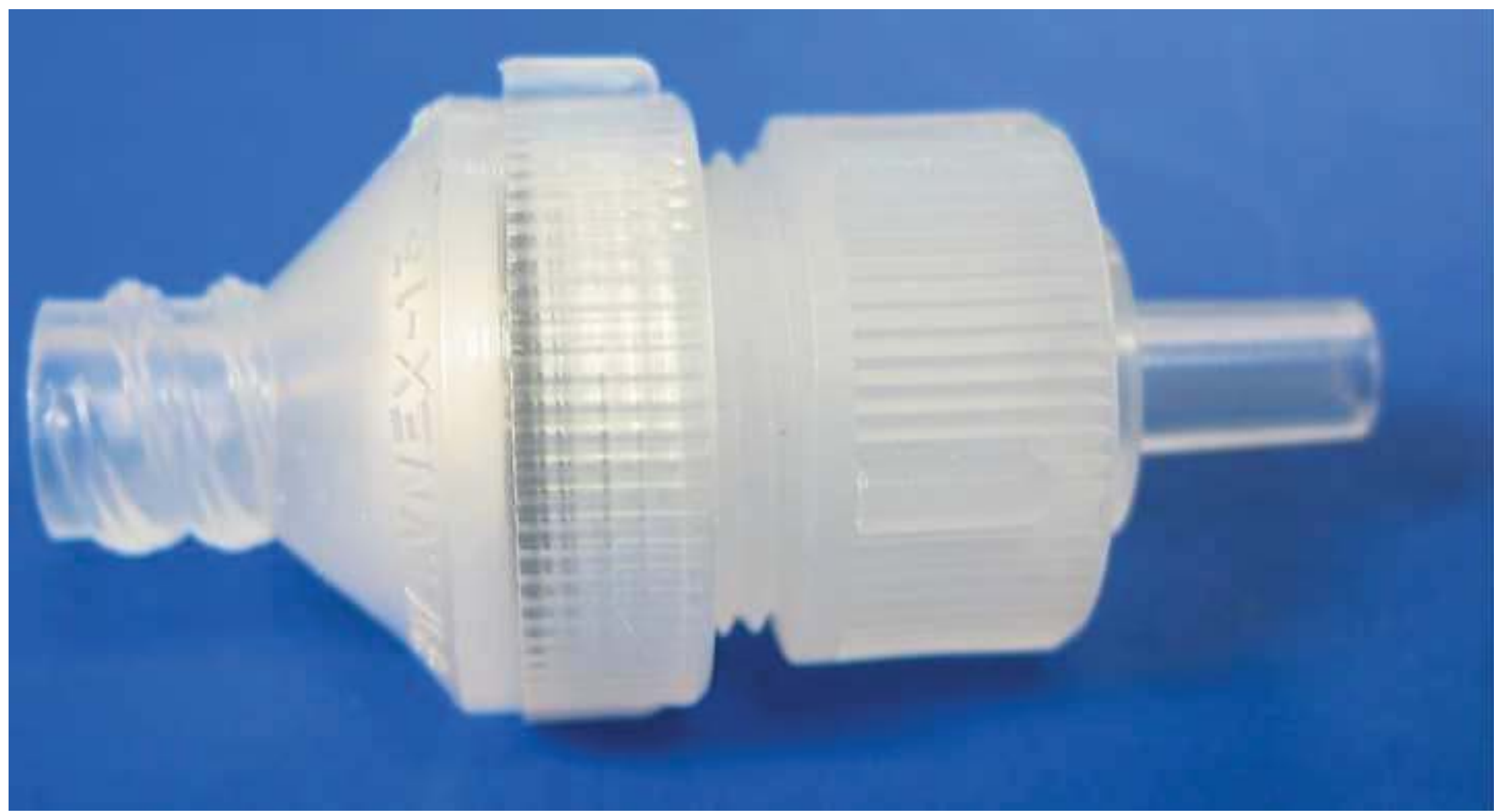




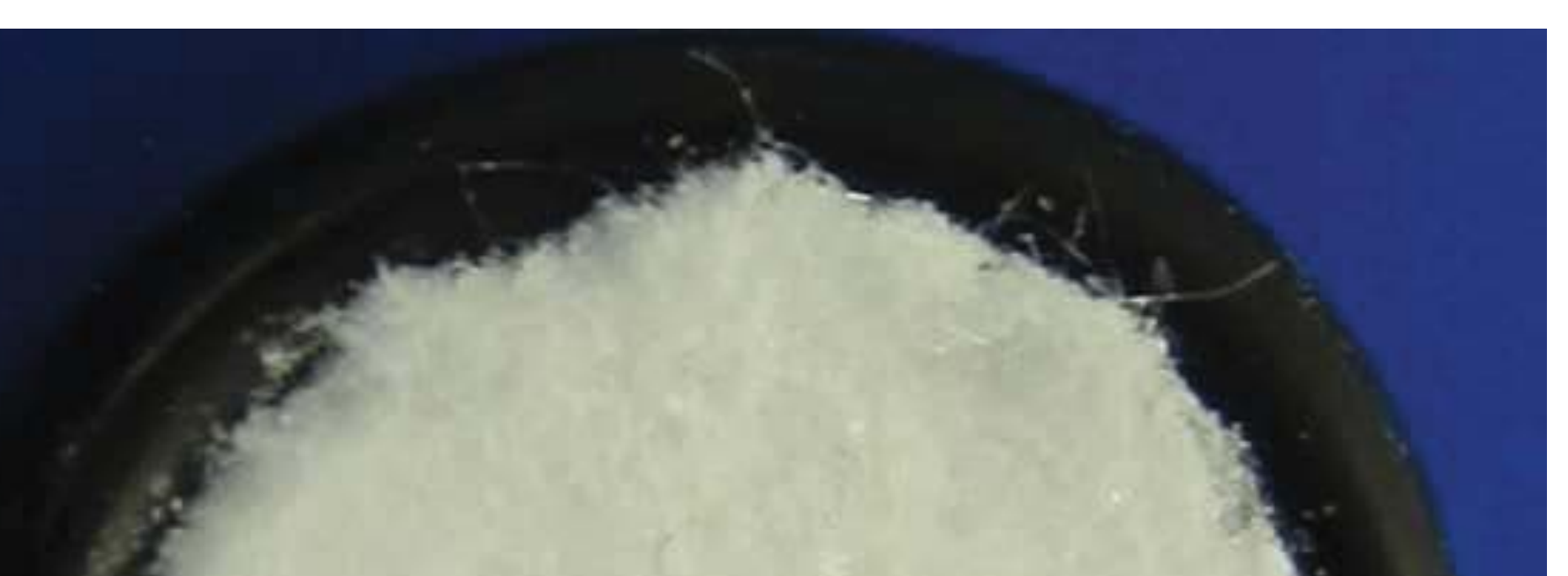




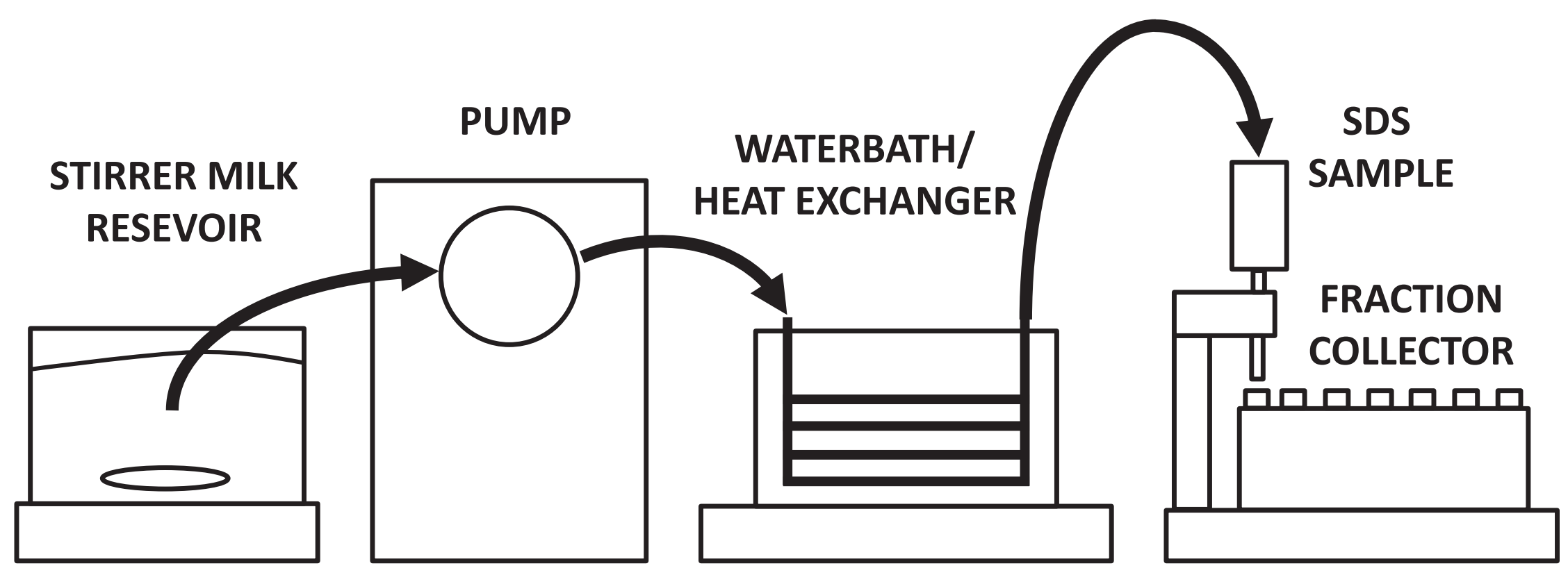




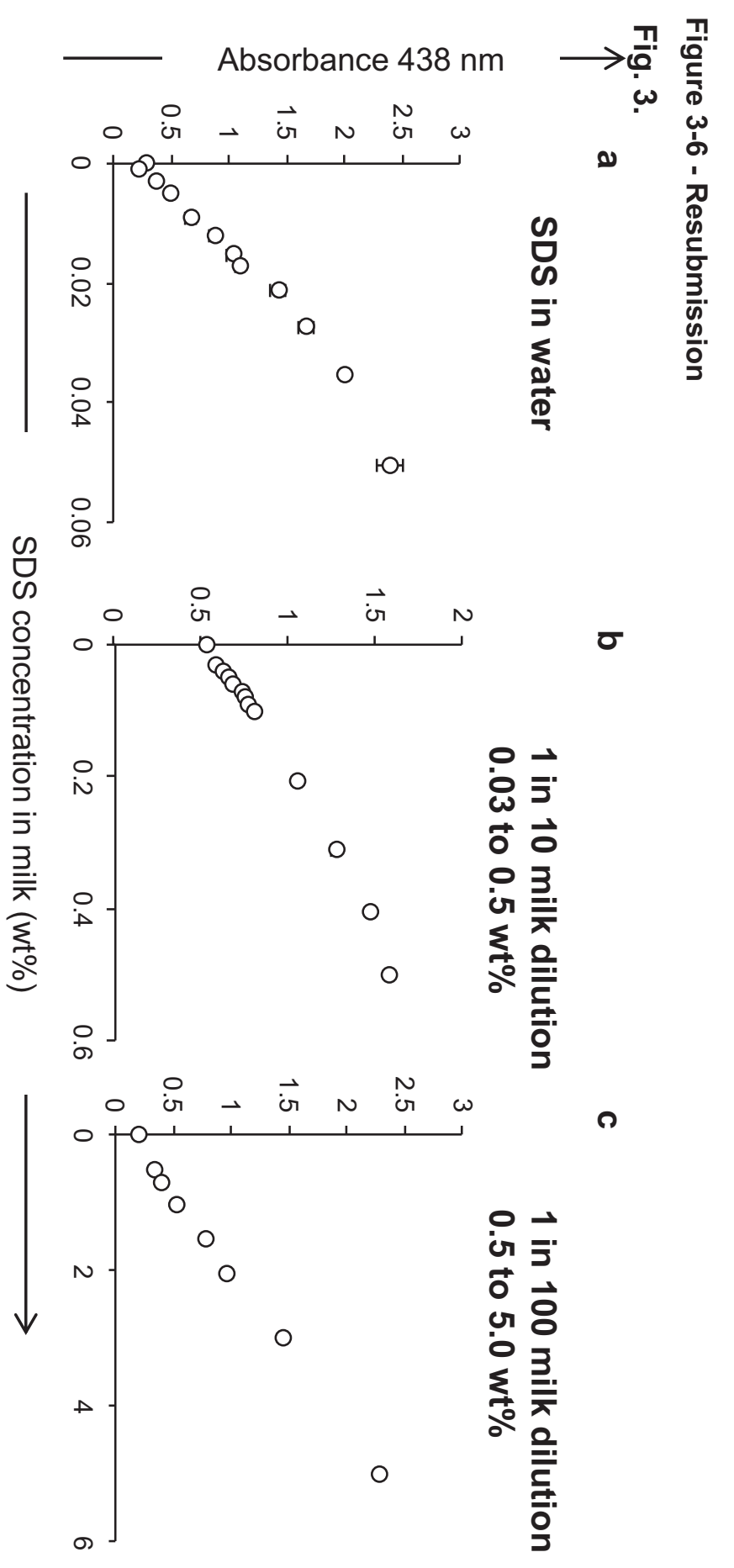




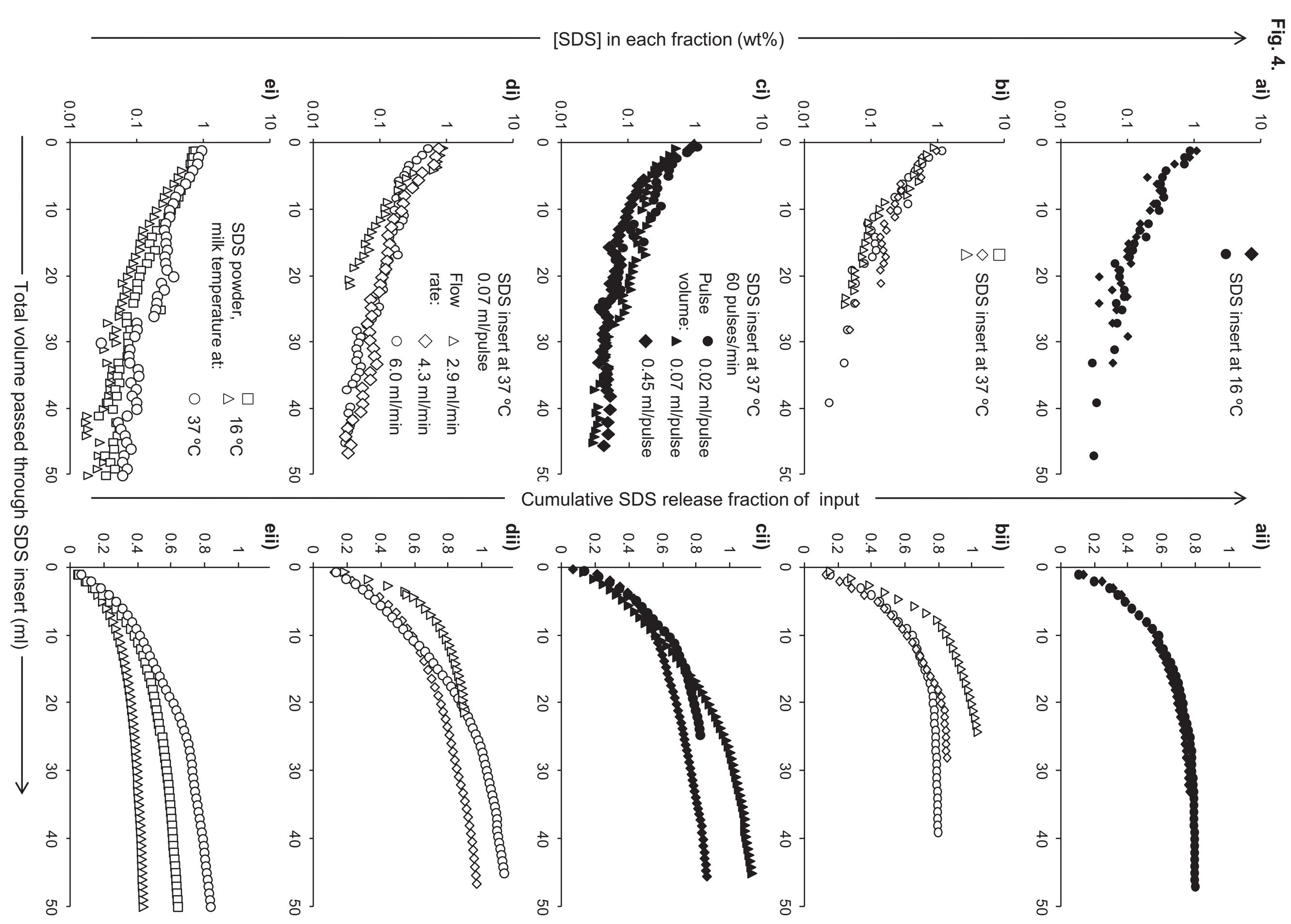


[SDS] in each fraction (wt\%)

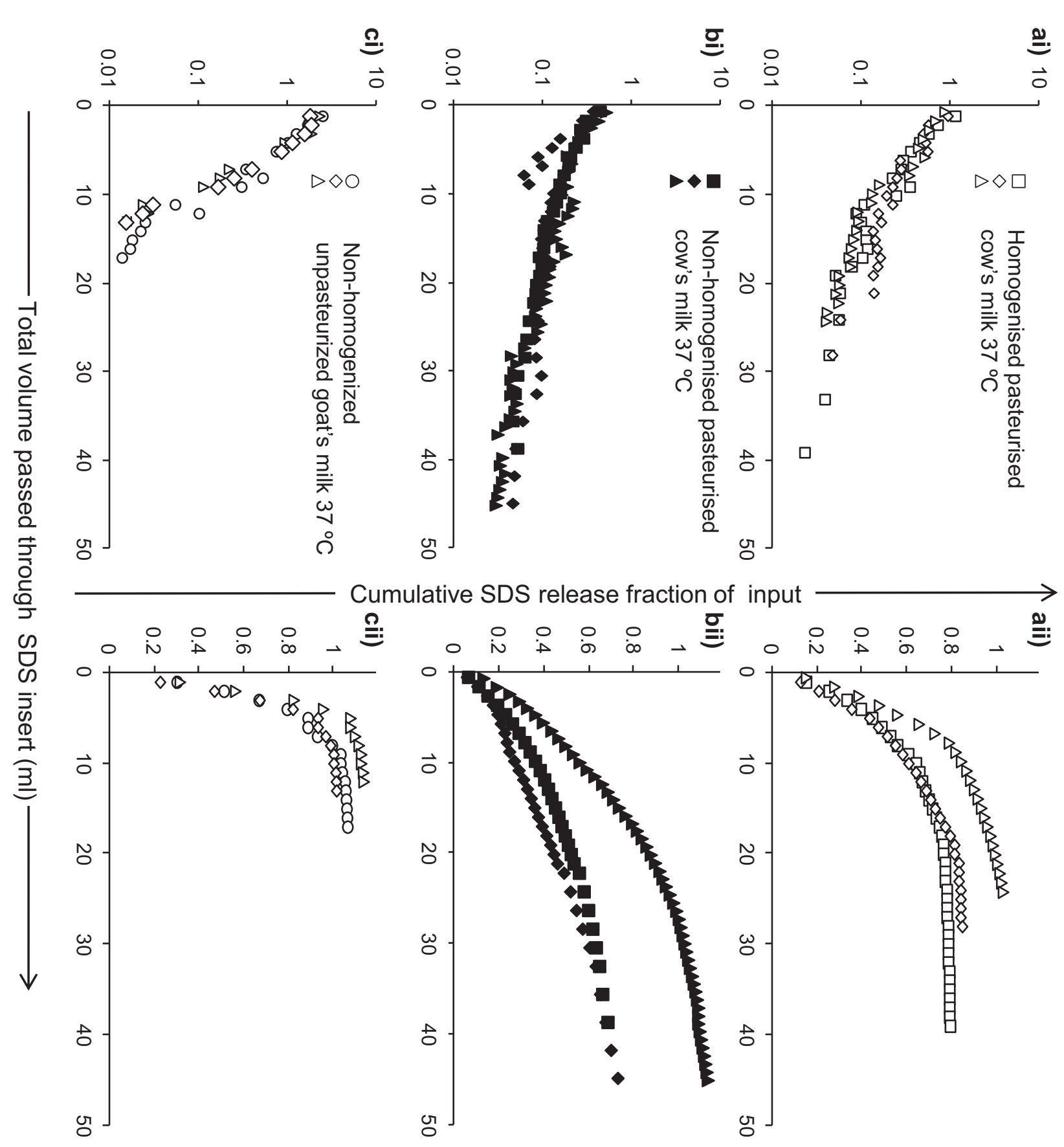


Correlated infected

H9/HIV ${ }_{\text {IIIB }}$ cellular content

(cells $/ \mathrm{ml} \times 10^{4}$ )

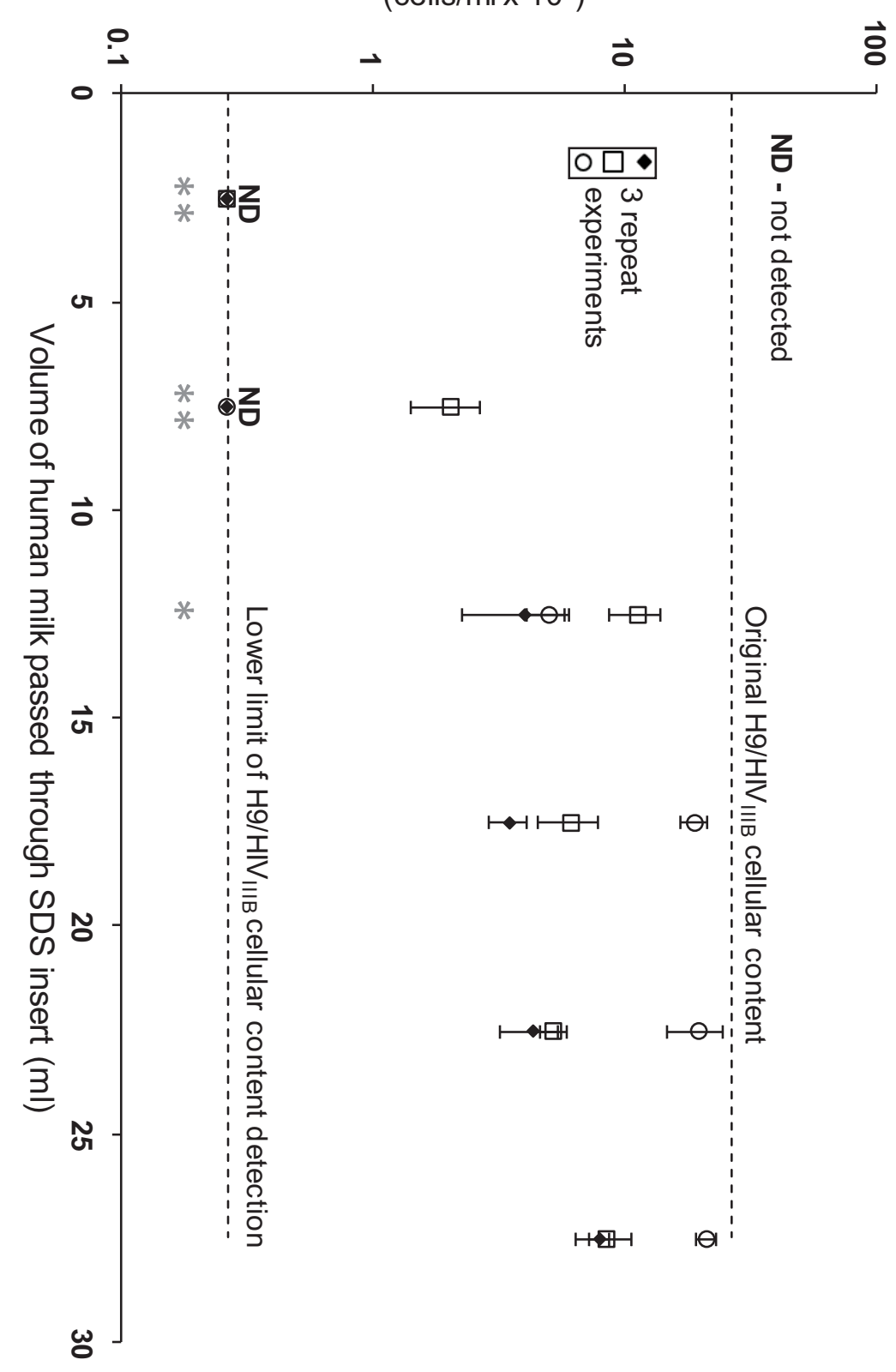

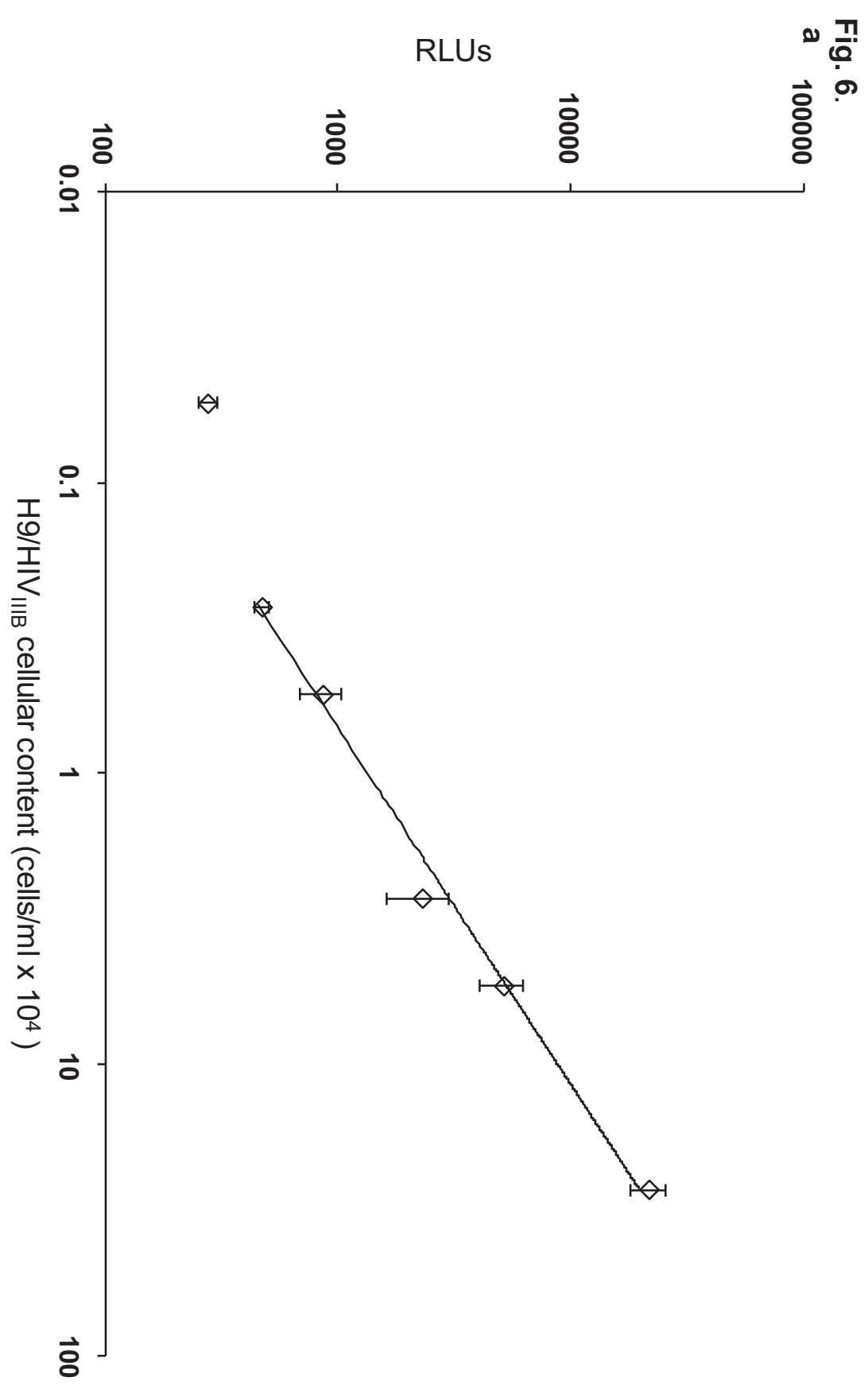

